\title{
Design and Synthesis of Molecular Scaffolds with Anti-infective Activity
}

\author{
Junjia Liu, ${ }^{\S}$ T. Aaron Bedell, Julian G. West and Erik J. Sorensen* \\ Department of Chemistry, Princeton University, Frick Chemical Laboratory, Princeton, New Jersey 08544, USA
}

\section{Introduction}

Over the last five decades, not only have few novel classes of antibiotics been discovered, none of them have earned a central position in the antibiotic market. Indeed, the vast majority of newly-approved antibiotics are derivatives of those discovered more than 50 years ago. ${ }^{1}$ An increasing number of pharmaceutical companies have exited from antibiotics research and, unsurprisingly, fewer antibiotics are approved each year. ${ }^{2}$ Some have (erroneously) interpreted this trend as proof that there is a sufficient antibiotics library to fulfill medical need. However, even a cursory survey of newspaper headlines will show that the adaptability of microbes has begun to outstrip the advances of pharmaceutical research.

One need look no further than the emergence of antibiotic-resistant ${ }^{3}$ bacterial strains to highlight the need for new classes of antibiotics. ${ }^{1,2}$ From the appearance of several cases of life-threatening methicillin-resistant Staphylococcus aureus (MRSA) infection in $2008^{4}$ to the escalating incidence of tuberculosis (TB), an often deadly infection by Mycobacterium tuberculosis that claims a life every ten seconds, ${ }^{5}$ it is clear that antibiotic resistance is a serious problem for modern society. Further example is provided from 2011, when Germany was suffering from a Escherichia coli outbreak in which over 3,500 people were infected by a mutant strain within three months. ${ }^{\text {aa,b }}$ Although antibiotics are not considered an appropriate treatment for diarrhea caused by E. coli infection, ${ }^{6 c, d}$ the unprecedented antibiotic-resistant strain found in this incident was a harbinger of more general resistance throughout the entire species. The resistance in this case, like many others, has been proposed to arise from inappropriate and excessive antibiotic use. As a result of this misuse, even vancomycin (14), often considered the last line of defense against serious bacterial infection, is now ineffective against several strains of resistant bacteria, including vancomycin-resistant Staphylococcus aureus (VRSA). ${ }^{7}$

The alarming decline in antibiotics research cannot be attributed to any single cause. It is tempting to blame the limited profitability of antibiotics due to the overwhelming majority of chronic bacterial infections occurring in developing countries which lack the economic power to purchase them ${ }^{8}$ However, the fact that thorough, well-funded antibiotic discovery projects in industry have met with little success illustrates that the problem is also scientifically non-trivial. ${ }^{9}$ Regardless, it has been recognized that the battle with drug-resistant bacterial strains is a crucial challenge for human society and legislation is frequently discussed towards both better regulating the use of antibiotics and incentivizing antibiotic research. ${ }^{10}$ Currently, several non-profit associations $(e . g$., the $T B$ Alliance and the Gates Foundation) and drug companies are backing initiatives to fight bacterial infections, including supplying discounted drugs to developing countries and continuing intensive research on infectious disease. Unfortunately, these efforts have proven insufficient thus far to stem the tide of antibiotic resistance, suggesting that more research in this area is necessary.

Most of the known antibiotics were isolated directly from living organisms or derived from natural products, but there are some classes of antibiotics that have been identified by screening synthetic small molecules. ${ }^{11,12}$ Currently, the market is dominated by only a few classes of traditional antibiotics (Figure 1A): $\beta$-lactams (including penicillins $(1)^{13}$ and cephalosporins $(2)^{14}$ ), quinolones (3), ${ }^{15}$ and macrolides (4) ${ }^{16}$ these major classes constitute about $75 \%$ of the market. The tetracyclines, ${ }^{17}$ aminoglycosides, ${ }^{18}$ and other classes of antibiotics (Figure 1C) constitute the remainder. ${ }^{19}$ Only a few novel classes of antibacterial compounds (e.g., pseudomonic acid, ${ }^{20}$ oxazolidinones, ${ }^{21}$ lipopeptides, ${ }^{22}$ and platensimycins ${ }^{23}$ ) have been identified in the past half century. $^{24}$ 
(a)<smiles>[R]C(=O)N[C@H]1C(=O)N2[C@@H](C(=O)O)C(C)(C)S[C@H]12</smiles>

penicillins (1)<smiles>[Y]c1cc2c(=O)c(C(=O)O)cn([Y])c2cc1[Y]</smiles>

quinolones (3)

(c)

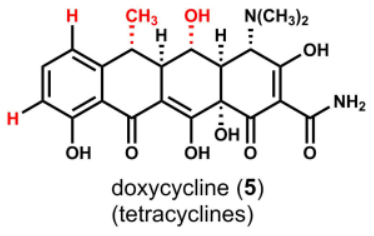<smiles>COc1nc2ccc(Br)cc2cc1C(c1ccccc1)[C@@](O)(CCN(C)C)c1cccc2ccccc12</smiles>

TMC207/R207910 (8) (Diarylquinolines)

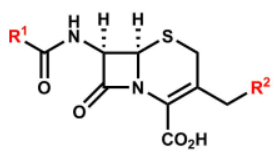

cephalosporins (2)

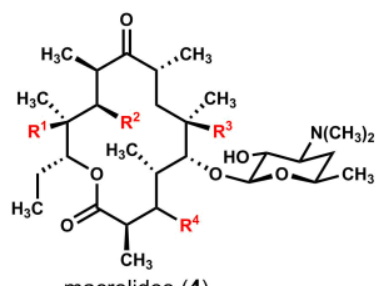

macrolides (4)

(b)
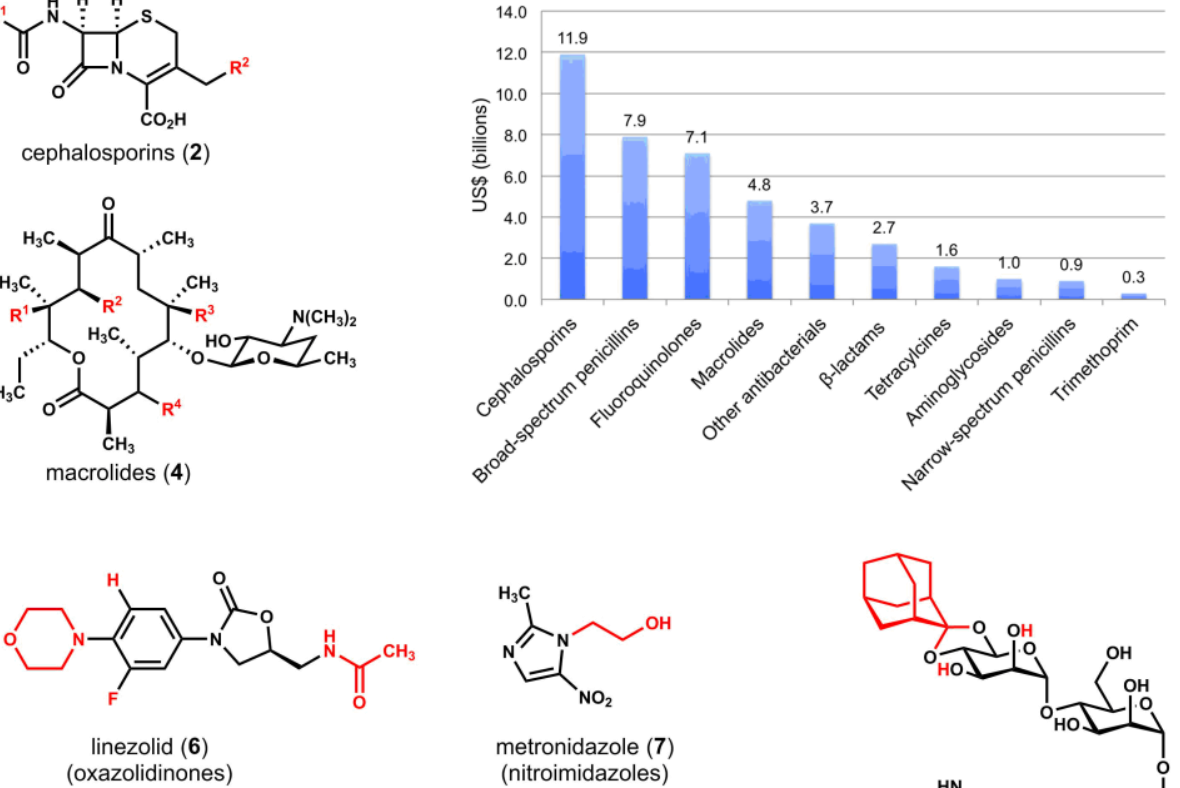

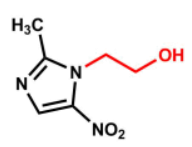

metronidazole ( 7 )

(nitroimidazoles)

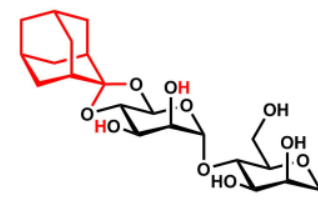

$+0$<smiles>Nc1ncc2cc(-c3c(Br)cccc3Br)c(N)nc2n1</smiles>
pyridopyrimidines (10)

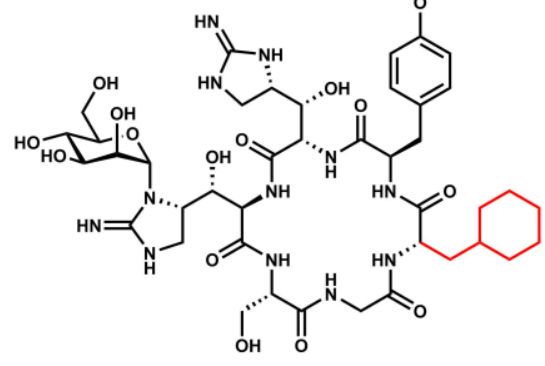

AC98-6446 (11)

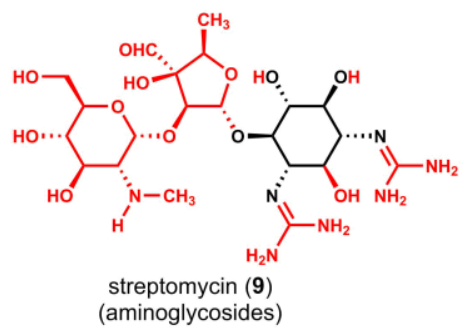
(aminoglycosides)<smiles>CCCCC(CN(O)C(=O)C(=O)N1CCCC1C(=O)Nc1ccc(F)c[n+]1[O-])C(=O)N1CCCC1C(=O)O</smiles>

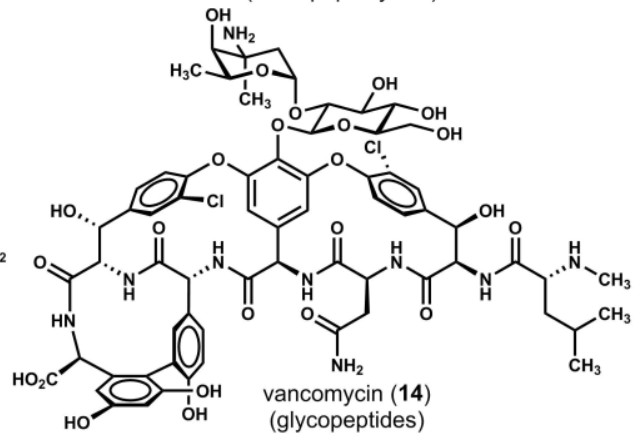<smiles>Cc1cc(NS(=O)(=O)c2ccc(N)cc2)no1</smiles>

sulphamethoxazole (15)

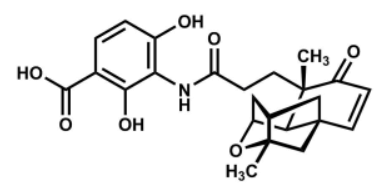

platensimycin (16)

\section{1}<smiles>CCCCCCCCCCC(=O)NC(CC)CC</smiles><smiles>COc1cc(Cc2cnc(N)nc2N)cc(OC)c1OC</smiles>

trimethoprim (17)<smiles>C/C(=C\C(=O)OCCCCCCCCC(=O)O)C[C@H]1OC[C@H](CC2OC2[C@H](C)C(C)O)[C@H](O)C1O</smiles><smiles>CCC(NC(=O)CNC(=O)C=O)C(=O)N[C@@H](CC(N)=O)C(=O)N[C@@H](C)C(N)=O</smiles><smiles>CCCC(NC(C)=O)C(=O)N[C@@H](CC)C(=O)NC(C(=O)CC)C(C)OCC</smiles><smiles>CC(CC(=O)O)C(NC(=O)C(CO)NC(=O)CN)C(=O)NC(CC(=O)c1ccccc1N)C(=O)O</smiles>

daptomycin (19) (lipopeptides) 
Figure 1. Chemical structures of traditional and underexplored antibiotic scaffolds. (a) Major antibiotic families in the market. (b) Antibiotic sales by class in 2009 in US\$ billions. ${ }^{19}$ (c) Selected naturally- and synthetically-derived antibiotics. Core scaffolds are in black and variable substitutions are in red; for compounds belonging to a particular class membership is indicated within parentheses.

Antibiotics in the same class usually suppress bacterial growth by inhibiting the same cellular target. When the targeted bacterial cellular component has changed due to genetic mutations, the interaction between a specific antibiotic and its target might be disturbed, resulting in resistance. ${ }^{25}$ Resistance could also occur if bacteria evolve to have (1) a hampered diffusion or transport mechanism, (2) an alternative metabolic pathway no longer susceptible to the antibiotics, (3) improved detoxification system (e.g., metabolic degradation and efflux pumps), or (4) any other alterations of pathways in which antibiotics are involved. ${ }^{3}$ In order to combat this resistance crisis there is an urgent need to find and develop new antibiotics with novel mechanisms of action. Not only are modern techniques (e.g. genomics-derived high-throughput screening) being developed for discovering new antibiotic scaffolds, ${ }^{26}$ there are also discussions on sustainable ways to optimize efficiency and shelf life, such as combination therapies and a shift in R\&D focus from broad-spectrum to narrow-spectrum antibiotics. ${ }^{27}$

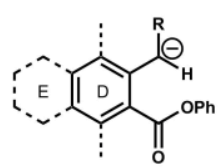

20

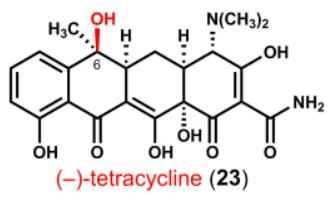

(-)-tetracycline (23)

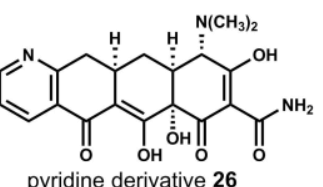

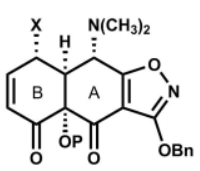

21

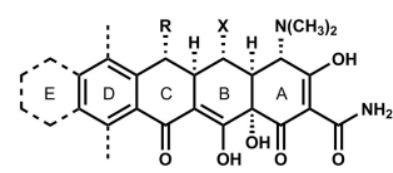

22

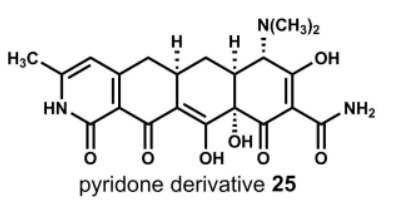

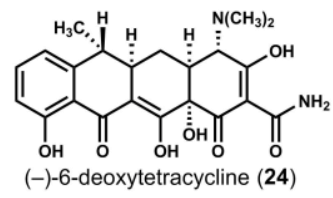
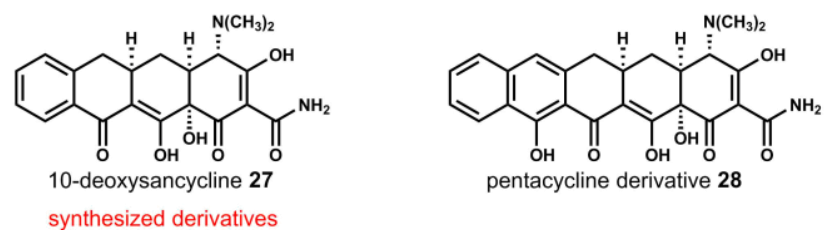

synthesized derivatives

Scheme 1. Convergent assembly of structurally diverse 6-deoxytetracyclines by Myers.

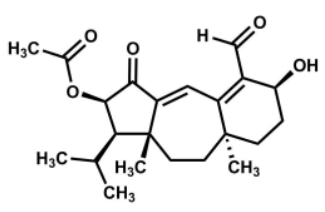

guanacastepene A (29)

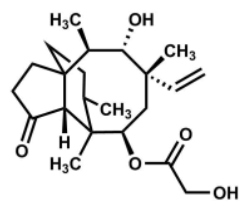

pleuromutilin (31)

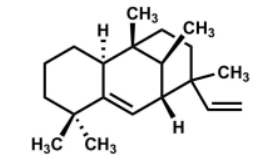

"edaxadiene" (33) (originally reported strucutre)
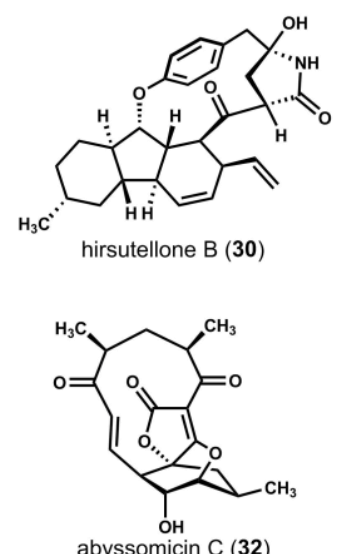

abyssomicin C (32)

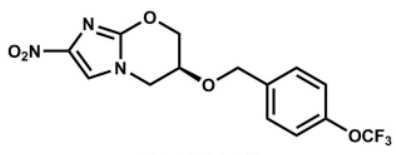

PA-824 (34)

Figure 2. Promising new scaffolds in antibacterial drug development. 
Our group has a long-standing interest in developing novel synthetic strategies to construct the molecular scaffolds of secondary metabolites and other biologically active compounds. Historically, chemical synthesis can and has offered an alternative to reliance on the isolation of natural products from what are often scarce sources. Additionally, the flexibility of the former provides an opportunity to produce a wide variety of analogues that would not be otherwise available from natural resources or semisynthetic modifications on natural products. Our entry into this area has been greatly encouraged by successful discovery and development of novel tetracycline analogues by Myers and co-workers (Scheme 1). ${ }^{28}$ The naturally occurring tetracycline compounds contain a hydroxyl group at the C-6 position; interestingly, semi-synthetic studies revealed that 6-deoxytetracyclines show better stability with comparable antibacterial activity. Myers and co-workers leveraged de novo synthetic design to rapidly access 6-deoxytetracyclines, and, with this purely chemical approach, greatly improved accessibility to promising, new tetracycline antibiotics. Their remarkable effort demonstrates the power of organic synthesis as a tool to expand the diversity of naturally occurring scaffolds and encourages the chemical community to explore diverse synthetic strategies for other antibiotic scaffolds. ${ }^{1,29}$ This perspective article summarizes our prior syntheses of the promising antibiotic scaffolds shown in Figure 2 and emphasizes our focus on diverse strategies for contending with the problems of forging topologically intricate and stereochemically complex ring systems.
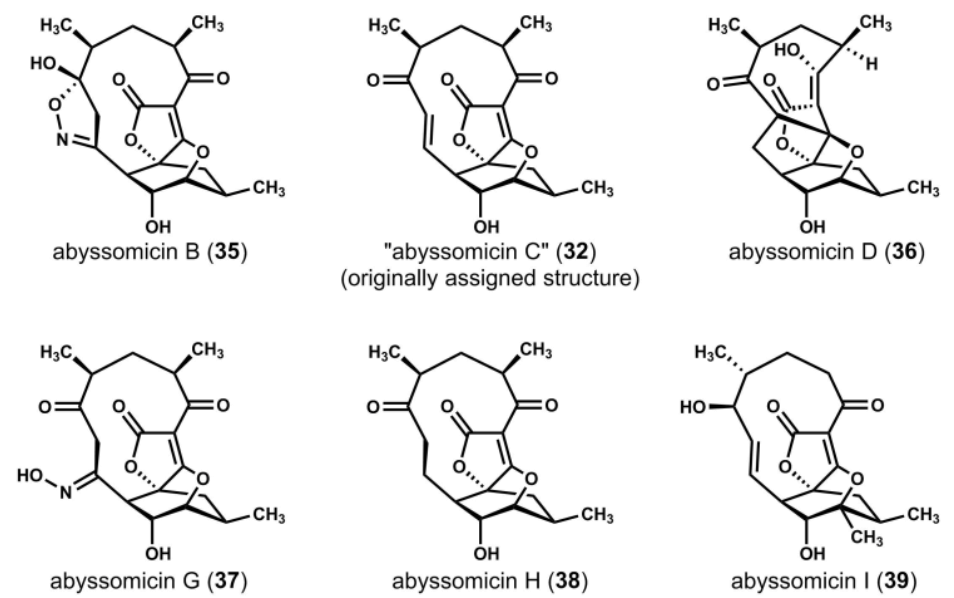

Figure 3. The abyssomicin family of antibacterial, marine natural products.

\section{First total synthesis of abyssomicin C featuring a nature-inspired, intramolecular Diels-Alder reaction}

Abyssomicin C (32), a novel anti-infective natural product, was first isolated from the marine actinomycete Verrucosispora maris AB-18-032 by Süssmuth and co-workers in 2004 (Figure 3). ${ }^{30}$ This compound contains a unique structural topology, featuring a tetronic acid moiety, an oxabicyclo[2.2.2]octane system, and an 11-membered macrocycle containing an $\alpha, \beta$ unsaturated ketone motif. Abyssomicin $\mathrm{C}$ is considered an attractive lead structure in drug development for its unique mode of action: suppressing bacterial growth via inhibition of para-aminobenzoic acid (PABA) biosynthesis from chorismate, a pathway commonly found in many microorganisms but, importantly, not in humans. ${ }^{30,31}$ Interestingly, among the first three identified compounds within the abyssomicin family (abyssomicins B, C and D), only abyssomicin C showed antibacterial activity (MIC $=4$ $\mu \mathrm{g} / \mathrm{mL}$ against MRSA; MIC $=13 \mu \mathrm{g} / \mathrm{mL}$ against VRSA). Based on those data, a hypothesis was put forward that the oxabicyclo[2.2.2] octane system might serve as a mimetic of chorismate to the enzymes, whose nucleophilic side chains bind to the enone domain in abyssomicin C. ${ }^{30}$ Aside from Verrucosispora, several compounds in the abyssomicin family have been found in other genera, such as abyssomicin I, which exhibits anti-tumor activity, from Streptomyces. ${ }^{32,33}$ 

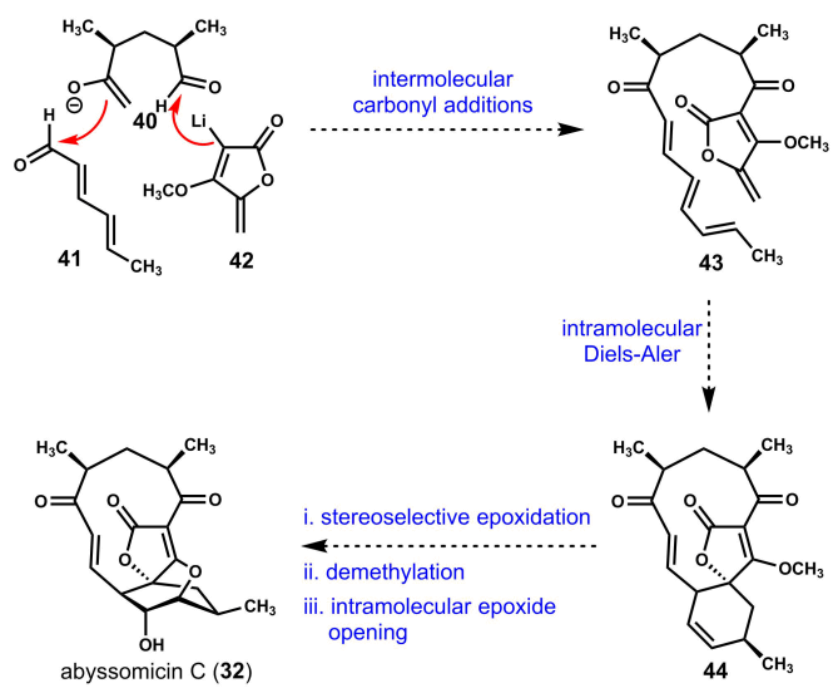

abyssomicin C (32)

Scheme 2. The concepts that guided our synthesis of abyssomicin C.

When considering the synthesis of natural products, biosynthetic pathways, shaped through untold years of evolution, exhibit exquisite creativity and efficiency. ${ }^{34}$ Synthetic chemists, charged with making these compounds in the laboratory, have often been inspired to mimic and compete with Nature's designs. Since its discovery in the 1920s, the Diels-Alder reaction has been a powerful synthetic tool to build molecular complexity ${ }^{35}$ and, unsurprisingly, this highly productive pericyclic reaction is speculated to be involved in some biosyntheses. ${ }^{36}$

A consideration of the full structure of abyssomicin $\mathrm{C}$ led to a plan to construct the oxabicyclo[2.2.2]octane substructure from an epoxidation/ring opening sequence executed on the cyclohexene moiety of $\mathbf{4 4}$, a tricycle that might emerge from a biomimetic intramolecular Diels-Alder reaction on trienone 43 (Scheme 2). Substrate 43 was envisioned to arise from three fragments via two, sequential carbonyl addition reactions. ${ }^{37}$

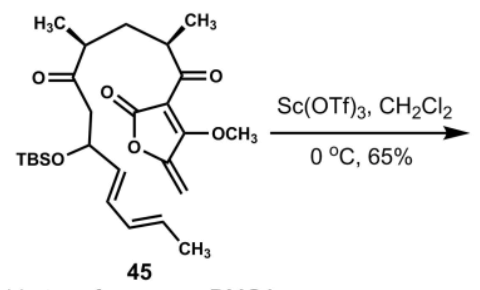

11 steps from meso-DMGA

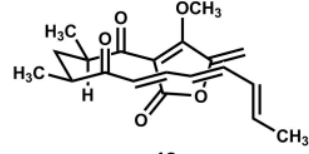

43

toluene, $100^{\circ} \mathrm{C}$

$4 \mathrm{~h}, 79 \%$

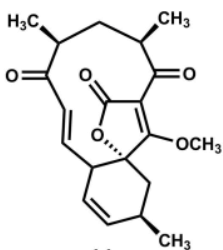

44

1. DMDO, acetone, $67 \%$

2. $\mathrm{LiCl}, \mathrm{DMSO}, 50^{\circ} \mathrm{C}$

quant.

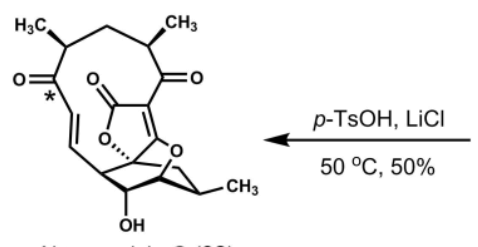

Abyssomicin C (32)

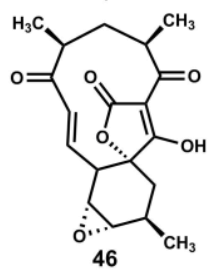


Scheme 3. Total synthesis of abyssomicin C via a biomimetic intramolecular Diels-Alder reaction. DMDO = dimethyldioxirane; DMSO = dimethyl sulfoxide; para-TsOH = para-toluenesulfonic acid monohydrate.

Intermediate 43 proved to be a viable Diels-Alder substrate; however, its handling was found to be non-trivial (Scheme 3). In an effort to avoid isolating 43, a one-pot $\beta$-elimination/Diels-Alder sequence on precursor $\mathbf{4 5}$ was planned. Through screening, it was found that treating $\mathbf{4 5}$ with lanthanum(III) triflate in toluene, with heating, promoted the desired cascade, yielding tricycle $\mathbf{4 4}$ as a single diastereomer. A site- and diastereoselective epoxidation of $\mathbf{4 4}$ followed by demethylation of the tetronic ester then furnished precursor $\mathbf{4 6}$ for the proposed final step. While the added stabilization through conjugation within the tetronic acid system depressed the nucleophilicity of the hydroxyl group in $\mathbf{4 6}$ under basic conditions, this hydroxyl will initiate a smooth trans-diaxial opening of the epoxide ring under acidic conditions to give a separable 1:1 mixture of the natural product abyssomicin $\mathrm{C}$ (32) and its related isomer 47 (Figure 4$){ }^{37}$
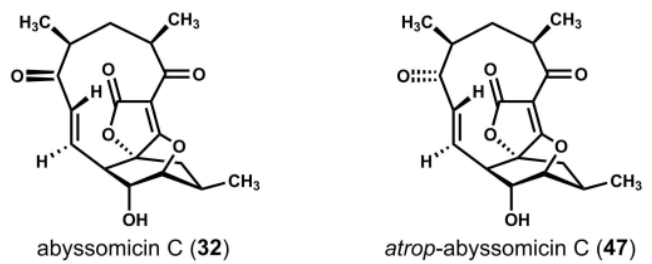

Figure 4. abyssomicin $\mathrm{C}$ and atrop-abyssomicin C.

Nicolaou and co-workers also encountered isomer $\mathbf{4 7}$ in the course of their chemical synthesis of abyssomicin $\mathrm{C}$ and were the first to confirm its structure by the method of X-ray crystallographic analysis; the isomer $\mathbf{4 7}$ that also arose when we treated compound 46 with acid is a stable atropisomer of abyssomicin C (32) (Figure 4). ${ }^{33 \mathrm{f}, \mathrm{g}, \mathrm{h}}$ The previously isolated abyssomicin C (32) and this new compound (47) differed in the orientation of the 11-membered ring moiety, a distinction made due to the rigidity of the skeleton. ${ }^{33 \mathrm{f}, \mathrm{g}, \mathrm{h}}$ Intrigued by this observation, Süssmuth and co-workers analyzed the culture filtrate from Verrucosispora and confirmed the presence of atrop-abyssomicin $\mathbf{4 7}$ in the strain, ${ }^{38}$ finding that it is actually a major component in the naturally occurring extracts and that the compound readily undergoes isomerization to abyssomicin $\mathrm{C}(\mathbf{3 2})$ under the original, acidic isolation conditions. $^{38}$

The chemical synthesis of abyssomicin compounds has provided opportunities for further research on their biological and pharmacological properties. Not only did the biomimetic synthesis featuring the Diels-Alder reaction help elucidate the biosynthesis pathway in vivo, ${ }^{39}$ it also provided additional abyssomicin-like compounds (such as stereoisomers and advanced intermediates) for biological evaluation. ${ }^{40}$ Chemical modifications to the enone moiety have helped confirm its role as an electrophile for the covalent modification of enzymes, with Cys-236 of ADC synthase being validated as an active nucleophilic partner. ${ }^{41}$ This insight provides yet another example of the utility of chemical synthesis. 


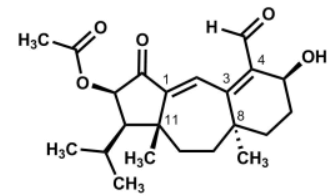

A (29)
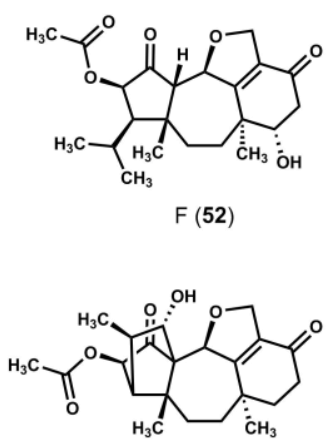

K (57)

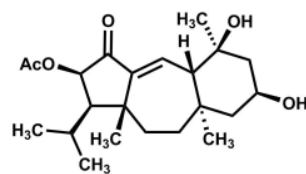

B (48)

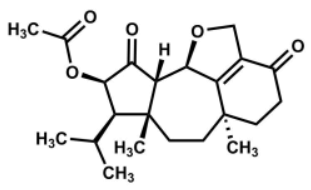

G (53)

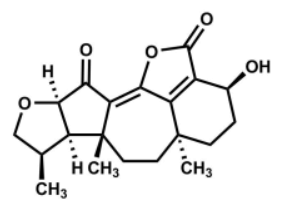

L (58)

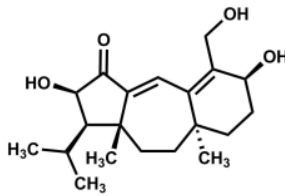

C (49)

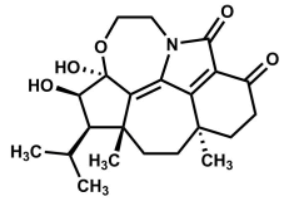

H (54)

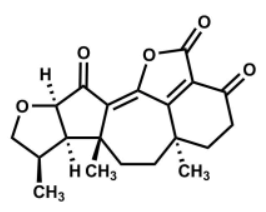

M (59)

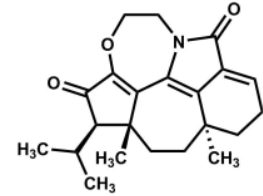

D (50)

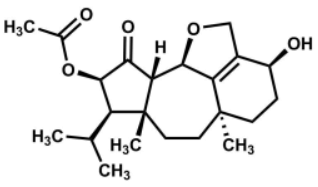

E (51)

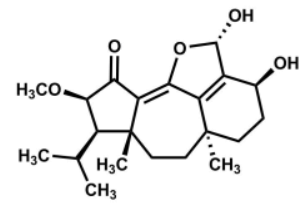

I (55)

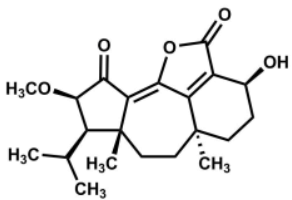

J (56)

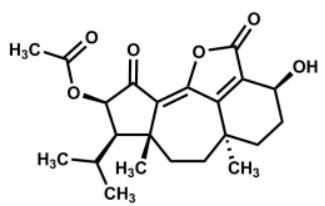

$\mathrm{N}(60)$

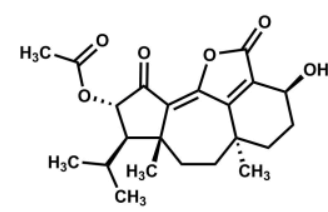

O (61)

Figure 5. The guanacastepene family of fungal-derived natural products.

\section{Construction of the tricyclic architecture of the guanacastepenes and related syntheses of guanacastepenes A and $\mathbf{E}$}

Clardy and co-workers first reported guanacastepene A (29) in 2000 after isolation from the fungus CR115. Subsequent to this, a family of diverse guanacastepenes was isolated from the same species (Figure 5), all of which share a core composed of fused 5-, 7-, and 6-membered rings. ${ }^{42}$ It has been found that guanacastepenes A and I, which contain a formyl group at C-4, display antibiotic activity through a cell membrane-disruption pathway. However, these compounds also exhibit toxicity to human red blood cells (RBCs) through an analogous mechanism, complicating their use as anti-microbials. Despite this problem, the potent activity exhibited against drug-resistant microbes is encouraging and efforts are ongoing to identify derivatives that can selectively lyse bacterial cells in the presence of human RBCs. ${ }^{43}$
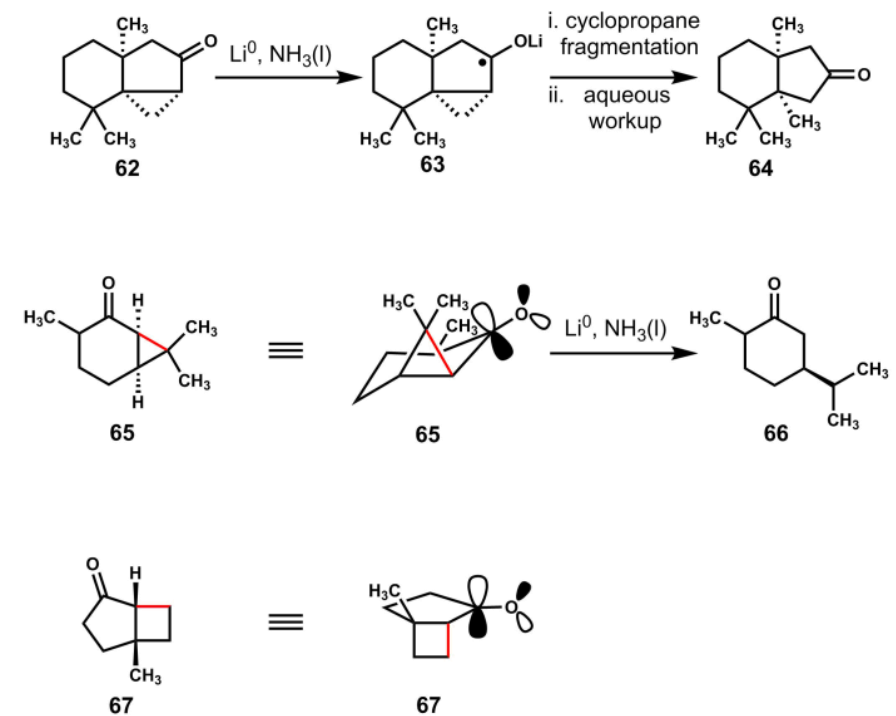

Scheme 4. Orbital overlap explanation for the ring-opening fragmentations of strained bicyclic ketones under one-electron reductant conditions. The $\mathrm{C}-\mathrm{C}$ bond possessing maximal overlap with the activated carbonyl $\pi$-system fragments.

Our plan for synthesizing the guanacastepenes hinged on a concept that arose from early investigations of stereoelectronically controlled, reductive fragmentations of conjugated cyclopropyl and cyclobutyl ketones (Scheme 4). Indeed, it was known that 
treatment of a strained carbon framework (e.g.62, 65, and 67) with a one-electron reducing reagent results in cleavage of the bond possessing the maximum overlap with the $\pi$-orbital of the activated carbonyl group. ${ }^{44,45}$ This fragmentation strategy was planned on multi-ring system 71, in which a selective ring opening would directly generate the 5-7-6 tricyclic core structure of the guanacastepenes. ${ }^{46}$ The original design called for a carbonyl addition of an organometallic reagent of the type $\mathbf{6 8}$ to aldehyde $\mathbf{6 9}$ to generate compound 70 (Scheme 5). An intramolecular [2+2] photocycloaddition would then afford 71, which, when treated with a single-electron reductant, would form the putative radical anion 72. The key, site-specific bond fragmentation (vide supra) would then reveal the central 7-membered ring and trigger a rapid $\beta$-elimination (see arrows in 73) to complete the construction of the guanacastepene framework shown as $\mathbf{7 4}$. For this attractive synthetic plan to work, the carbon-centered radical shown in $\mathbf{7 3}$ would need to undergo a simple reduction to the corresponding methylene shown in $\mathbf{7 4 .}$
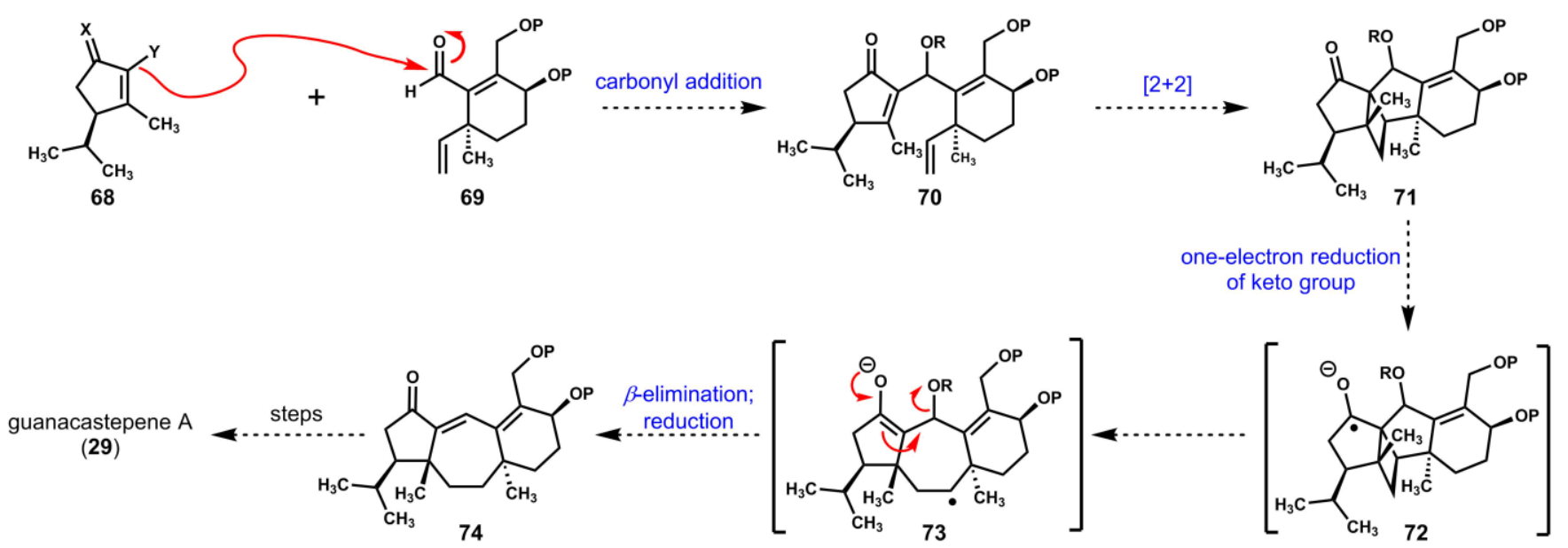

Scheme 5. Original synthetic strategy towards guanacastepene core.

In the first test of this concept, 75 and 76 were elaborated to substrate 77 (Scheme 6) in a few steps. In the pivotal step, a reduction of pentacycle $\mathbf{7 7}$ with samarium iodide unexpectedly gave rise to the interesting tetracycle $\mathbf{7 8} .^{46}$ Although unanticipated, this result was still encouraging. Seemingly, the originally designed fragmentation does occur on substrate 77, but the putative carbanion $\mathbf{8 1}$ (or perhaps the secondary radical preceding $\mathbf{8 1}$ ) readily undergoes an intramolecular, transannular conjugate addition to afford the cyclobutane-containing $\mathbf{7 8 .}$

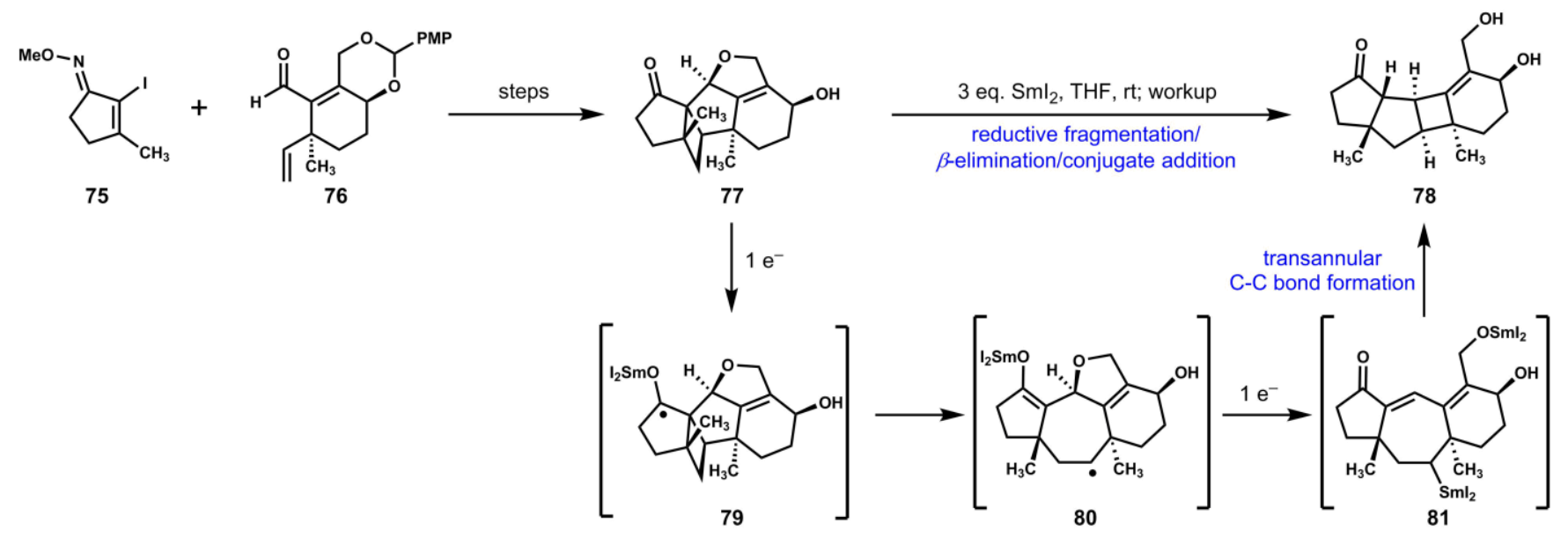

Scheme 6. Original strategy led to an unexpected novel tetracycle. 

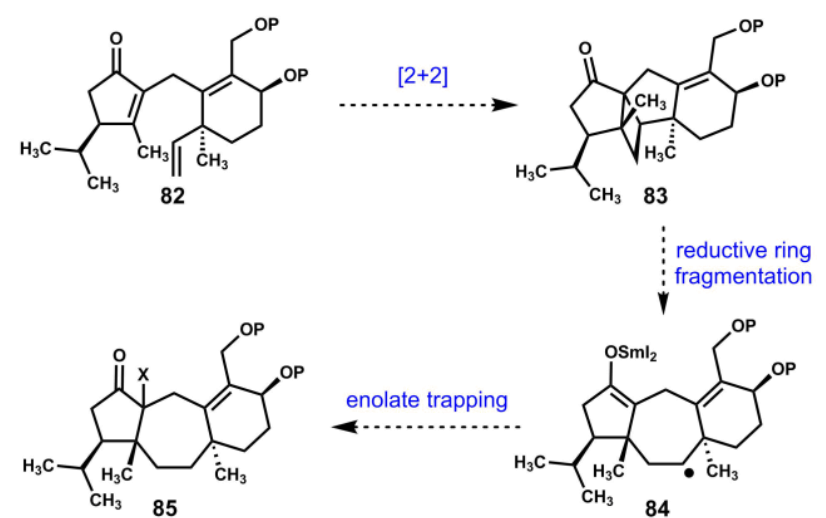

Scheme 7. The revised convergent design towards guanacastepenes.<smiles>CCC1=C(C)C(C(C)C)CC1=O</smiles>

86<smiles>CCCC1CCC2O[C@@H](C)OCC2=C1CO</smiles>

87

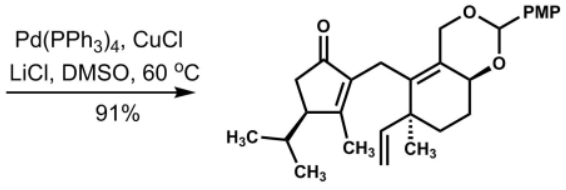

88

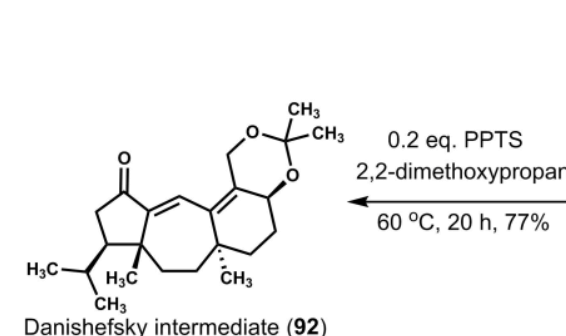

Danishefsky intermediate $(\mathbf{9 2})$
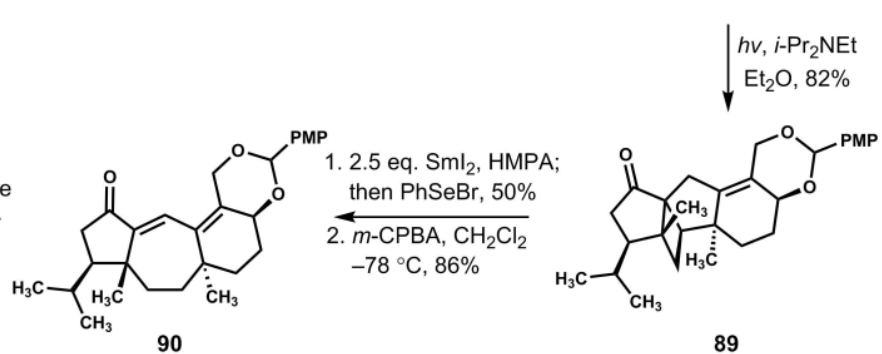
5 steps $\mid \begin{gathered}\text { Danishefsky et al. } \\ \text { Angew. Chem. In. Ed. }\end{gathered}$ 2002, 41, 2188-2191.
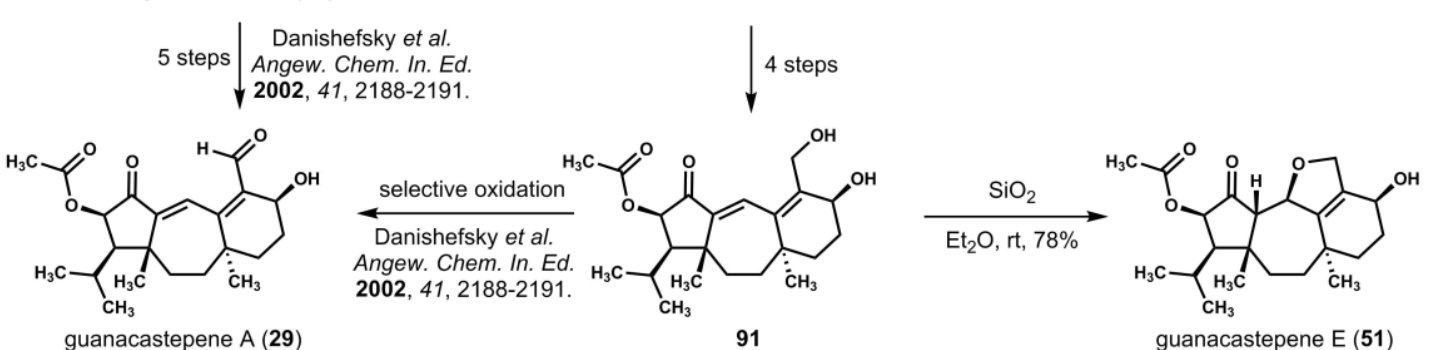

Scheme 8. Synthesis of the guanacastepene architecture featuring a $[2+2] /$ reductive fragmentation/elimination sequence and its application in total synthesis of guanacastepenes A and E. DMSO = dimethyl sulfoxide; HMPA = hexamethylphosphoramide; $m$-CPBA = 3-chloroperoxybenzoic acid; PMP = para-methoxyphenyl; PPTS = pyridinium para-toluenesulfonate .

Modified substrate 82 (Scheme 7) was designed with the aim of solving this problem by circumventing the formation of the enone motif from the $\beta$-elimination, which had previously occurred on $\mathbf{8 0}$ (Scheme 6). Instead, an enolate trapping of $\mathbf{8 4}$ by a reagent like phenylselenyl bromide $(\mathrm{PhSeBr})$ would generate $\mathbf{8 5}$, which would be available for a late-stage elimination. The implementation of this revised strategy commenced with a Stille coupling between fragments $\mathbf{8 6}$ and $\mathbf{8 7}$ (Scheme 8), followed by the $[2+2] /$ reductive fragmentation/enolate trapping/elimination sequence from $\mathbf{8 8}$. This sequence of chemical reactions permitted access to the advanced guanacastepene intermediate 90. From this vantage point, guanacastepenes A and $\mathrm{E}$ were available in a few steps each, ${ }^{46}$ providing a short, reliable synthesis to allow for later diversification.

\section{A synthesis of the reported structure of edaxadiene enabled a structure revision}


After pathogenic microorganisms enter a macrophage cell and are absorbed by the phagosome, the phagosome will be induced to fuse with a lysosome, resulting in the foreign cell being digested in a low $\mathrm{pH}^{\text {evironment. }}{ }^{47}$ Interestingly (and alarmingly), certain pathogens, such as Mycobacterium tuberculosis, are able to inhibit this process. It is known that this inhibitive effect is partially related to mycobacterial cell surface lipids, but other effectors of this inhibition are still unclear. ${ }^{48}$ In 2009 , Peters and co-workers isolated a diterpene compound, edaxadiene (33), from wild-type M. tuberculosis (Figure 6$)^{49}$ demonstrating a close correlation with tuberculosis activity. Indeed, the genetic operon responsible for the in vivo production of edaxadiene was only observed in pathogenic strains and edaxadiene was shown in vitro to directly inhibit phagosome maturation. ${ }^{49,50}$ Although 33 itself is not an effective antibiotic, efforts to unveil the biosynthetic pathway of $\mathbf{3 3}$ and its molecular target in host cells are underway. Towards better understanding and combating this problematic characteristic of M. tuberculosis, increased access to edaxadiene and related compounds through chemical synthesis would be invaluable.

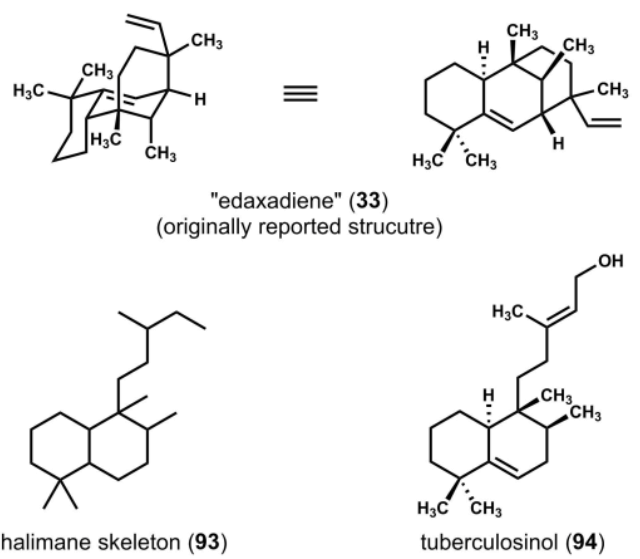

Figure 6. Original proposed structure of edaxadiene.

The originally proposed structure of $\mathbf{3 3}$ contains a halimane skeleton containing five contiguous stereogenic centers in its bicyclo[3.3.1]nonane framework with one quaternary stereocenter not assigned. In our approach to the problem of synthesizing this structure, an intramolecular ketone allylation was envisioned to convert enone 95 to the unusual bicyclo[3.3.1]nonane structure 96 (Scheme 9). A subsequent annulation of the left-most ring would then furnish 97 and give rise to the proposed structure of edaxadiene (33) after deoxygenation. ${ }^{51}$

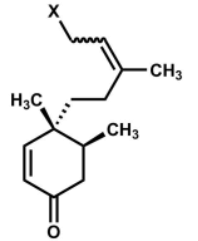

95

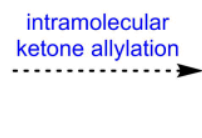

96
$\vdots$
$\vdots$
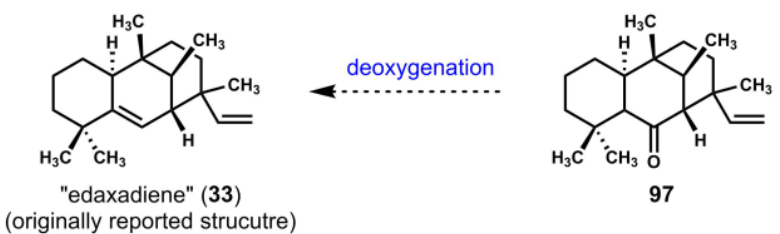

Scheme 9. Synthetic strategy towards "edaxadiene". 
The desired annulation on precursors 98a and 98b, respectively, could be effected via an oxidative cyclization in the presence of manganese(III) acetate and copper(II) acetate, giving bicyclo[3.3.1]nonanes 96a and 96b, respectively (Scheme 10). ${ }^{52}$ Even at this early stage, however, a discrepancy between these synthetic intermediates and previously reported ${ }^{13} \mathrm{C}$ shifts at $\mathrm{C}-13(\Delta \delta>40$ ppm) started to appear. To investigate this emerging NMR data difference, both 96a and 96b were converted into alkenes 100a and

100b, respectively. Although the volatility of these compounds limited their isolated yields, close relatives of the proposed edaxadiene structure (33) were available for comparison. Through ${ }^{13} \mathrm{C}$ NMR analysis, a substantial mismatch for the quaternary carbons supported the hypothesis that the previously assigned edaxadiene structure might be incorrect. A survey of the literature revealed a related, known compound, nosyberkol (101), which was first isolated from the Red Sea sponge Raspailia sp. ${ }^{53}$ and has been reported as a metabolite of $M$. tuberculosis. ${ }^{54}$ However, the fact that the NMR spectra of nosyberkol and edaxadiene $(\mathbf{3 3})$ were obtained in different deuterated solvents complicated the comparison of their spectral data.
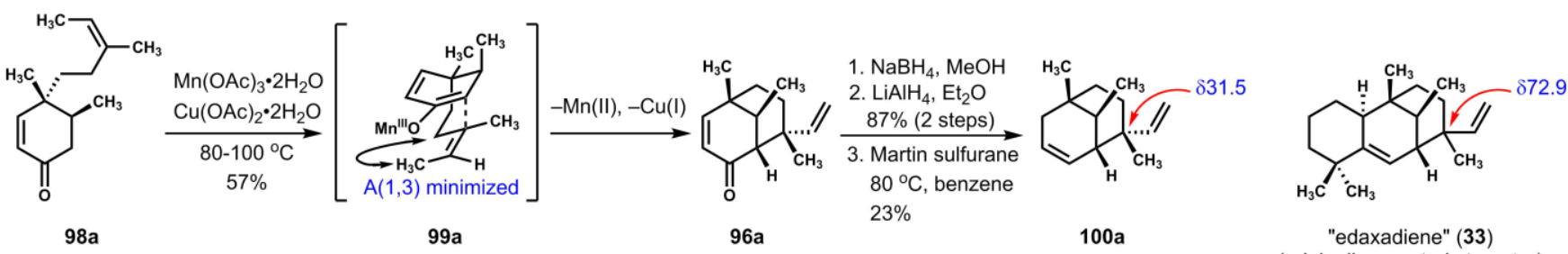

"edaxadiene" (33) (originally reported strucutre)

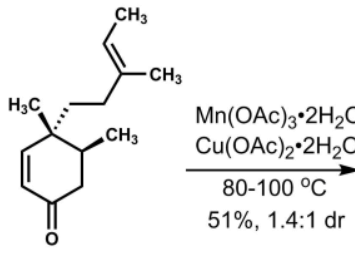

$98 b$

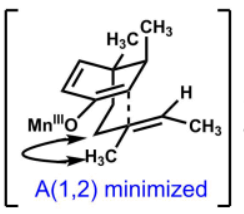

$99 \mathrm{~b}$

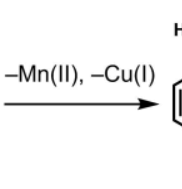

$96 b$

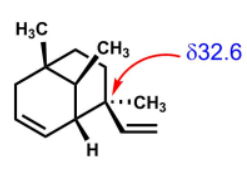

$100 \mathrm{~b}$

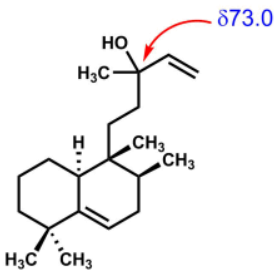

nosyberkol (101)

Scheme 10. Discrepancies in ${ }^{13} \mathrm{C}$ NMR chemical shifts indicated incorrect structural assignment of edaxadiene.

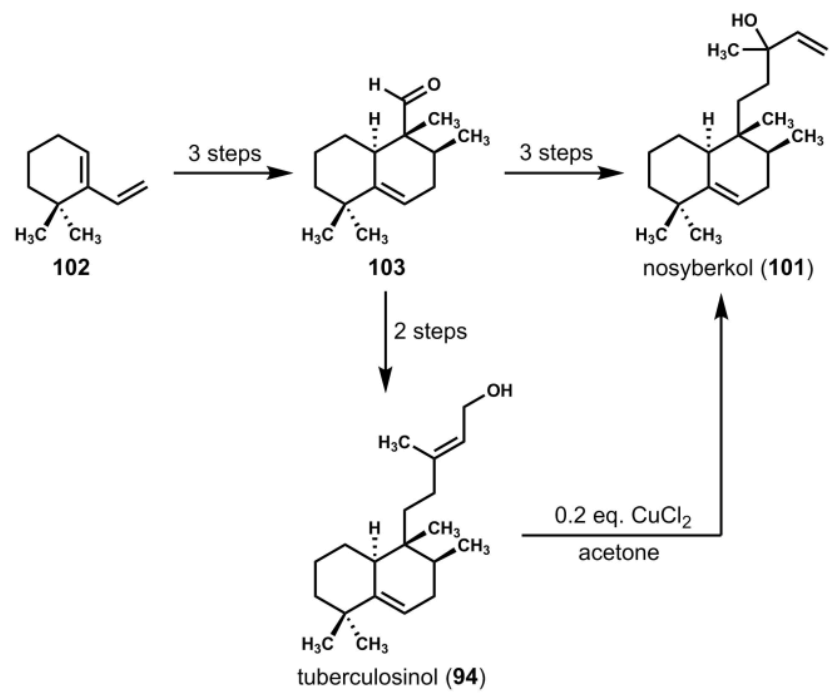

Scheme 11. Synthesized nosyberkol confirmed a structural revision of "edaxadiene".

To interrogate whether the structure reported as $\mathbf{3 3}$ was in fact nosyberkol (101), a rapid synthesis of $\mathbf{1 0 1}$ was designed and executed (Scheme 11). The synthetic nosyberkol thus obtained was a mixture of inseparable diastereomers, the NMR data of which matched those reported for edaxadiene. ${ }^{55}$ Furthermore, this result indicated that the previously isolated natural product was in fact a mixture of epimers at the allylic position. Finally, nosyberkol (101) was afforded by using the conditions reported to convert 
tuberculosinol (94) to "edaxadiene (33)", with further studies showing that $N, N$ '-dicyclohexylcarbodiimide (DCC) is not required to trigger this transformation.

The structural revision of edaxadiene and concise synthesis of its actual structure, nosyberkol (101), exemplifies an important role of chemical synthesis: it not only serves as an alternative resource for supplying larger quantities of scarce natural products and related compounds for asking important biological questions, but also provides a means to support or refute tentatively proposed structural and configurational assignments of naturally occurring compounds. ${ }^{56}$

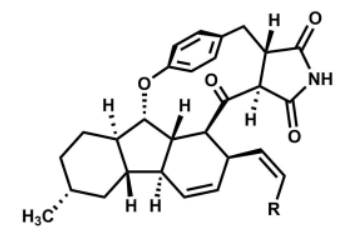

hirsutellone $\mathrm{A}(\mathbf{1 0 4}): \mathrm{R}=\mathrm{H}$ hirsutellone $\mathrm{D}(\mathbf{1 0 5}): \mathrm{R}=\mathrm{CH}_{3}$

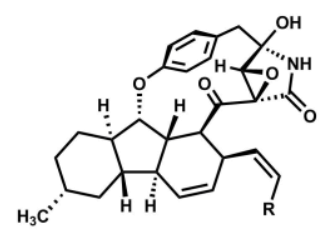

hirsutellone C (107)

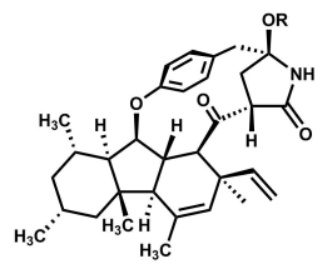

GKK1032 $A_{1}(110): R=\mathrm{CH}_{3}$ GKK1032 $A_{2}$ (111): $R=H$

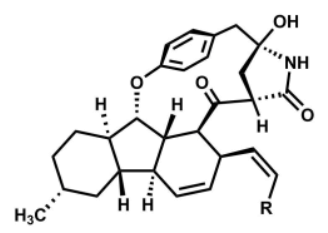

hirsutellone $\mathrm{B}(\mathbf{3 0}): \mathrm{R}=\mathrm{H}$ hirsutellone $\mathrm{E}(106): \mathrm{R}=\mathrm{CH}_{3}$

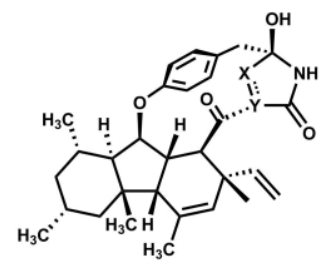

pyrrocidine $\mathrm{A}(\mathbf{1 0 8}): \mathrm{X}, \mathrm{Y}=\mathrm{CH}=\mathrm{C}$ pyrrocidine $\mathrm{B}$ (109): $\mathrm{X}, \mathrm{Y}=\mathrm{CH}_{2}-\mathrm{CH}$

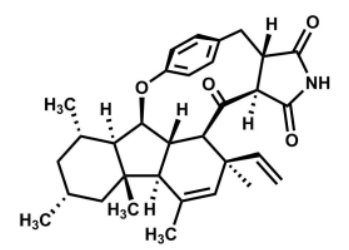

GKK1032 B (112)

Figure 7. Hirsutellones, pyrrocidines and GKK1032s share a common skeleton.

\section{Rapid construction of hirsutellone cores featuring a dioxenone-opening/intramolecular Diels-Alder/intramolecular ketene-trapping cascade}

Recently, a new class of polyketide antibiotics has been isolated from various fungi, a class including the hirsutellones from Hirsutella nivea BCC 2594 and Trichoderma sp. BCC $7579,{ }^{57}$ the GKK1032 compounds from penicillia, ${ }^{58}$ and the pyrrocidines from LL-Cyan426 (Figure 7). ${ }^{59}$ All of these compounds share a common and hitherto unknown skeleton containing a decahydrofluorene subunit and a highly strained, oxygen-containing macrocycle. Although the specific mode of action for these compounds is unclear, their potent antimicrobial activity has attracted the attention of the antibiotic research community. ${ }^{57,58,59}$

Hirsutellones A (104), B (30) and C (107) share the aforementioned decahydrofluorene moiety with identical patterns of substitution and stereochemistry, with their differences being focused on their macrocyclic subunits. Towards accessing these compounds and related analogues, a general synthetic strategy was proposed to build the hirsutellones, wherein precursor $\mathbf{1 1 3}$ could be constructed rapidly from four fragments via a pair of Wittig reactions ${ }^{60}$ and a Tsuji-Trost etherification (Scheme 12$) .{ }^{61}$ When heated, a retro-hetero-Diels-Alder reaction could occur on the dioxenone moiety of $\mathbf{1 1 3}$, and the resulting intermediate $\mathbf{1 1 4}$ would undergo a highly productive intramolecular ketene addition/Diels-Alder cascade to furnish an advanced hirsutellone scaffold (115) suitable for further modification. ${ }^{62}$ 


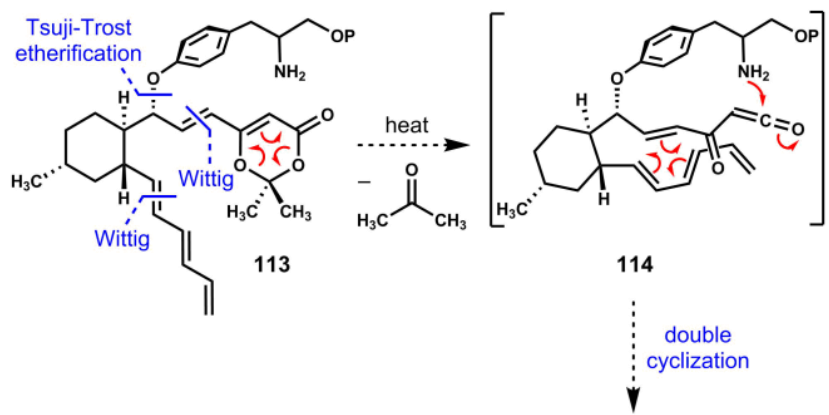

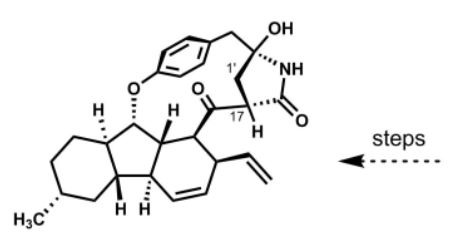

hirsutellone B (30)

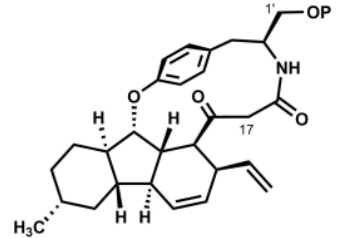

115

Scheme 12. Synthetic strategy towards hirsutellone B.

Compound 116, approximately 15 linear steps from commercially available compounds, was prepared in order to demonstrate the viability of a simplified dioxenone-opening/intramolecular Diels-Alder sequence with methanol present as a co-solvent to trap the intermediate acyl-ketene (Scheme 13). The envisioned four-fragment strategy mentioned above proved amenable to the construction of a variety of advanced precursors, including 119, 122 and 125, and each of these smoothly underwent the proposed dioxenone-opening/intramolecular Diels-Alder/intramolecular ketene-trapping sequence in respectable yields. ${ }^{62,63}$

Efforts to advance these and other, related intermediates in pursuit of a total synthesis of hirsutellone B using the strategy outlined above were ultimately unsuccessful. ${ }^{63}$ Attempts to join C-17 and C-1' utilizing a multitude of methods to construct the $\gamma$ lactam (115 to 30, Scheme 12) failed to produce any of the desired bond formation, a result postulated to arise from a lack of proximity in such a rigid ring system. The variety of synthetic studies towards the hirsutellones and other natural products containing the decahydrofluorene core ${ }^{64}$ include two total syntheses of hirsutellone B, reported by the Nicolaou ${ }^{65 a}$ and Uchiro ${ }^{65 b}$ groups, respectively. Critically, Nicolaou and coworkers constructed the highly strained 13-membered macrocycle by a RambergBäcklund reaction, while Uchiro used a copper-catalyzed Ullmann-type etherification; both of these syntheses access the 13membered motif via ring-contraction from a less strained 14-membered macrocycle (or metallomacrocycle) and share a conceptual similarity with our original approach. ${ }^{65}$ Having exhausted all other means for constructing the para-cyclophane motif, we found that we could modify our retro-hetero-Diels-Alder/intramolecular Diels-Alder sequence to intercept a late-stage diol intermediate from the synthesis reported by Nicolaou, ${ }^{65 a}$ thus achieving a formal synthesis of hirsutellone B. 


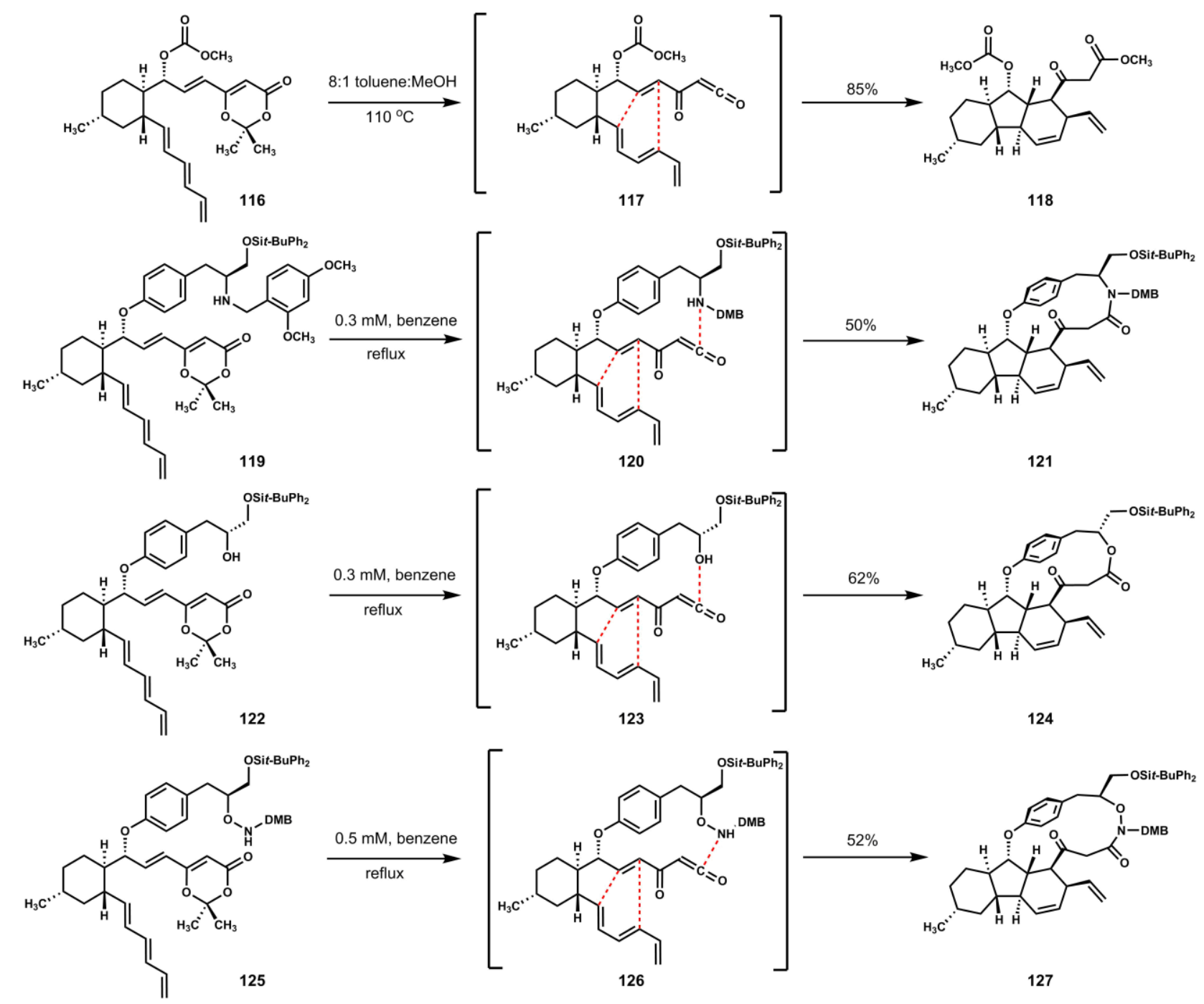

Scheme 13. A tandem acylketene formation/Diels-Alder/intramolecular ketene trapping sequence afforded hirsutellone cores. $\mathrm{DMB}=2,4$-dimethoxybenzyl.

\section{Rapid synthesis of a pleuromutilin 5-8-6 tricyclic skeleton.}

Pleuromutilin (31), a diterpene containing a unique 5-8-6 tricyclic skeleton, was first isolated from fungi by Kavanagh in the early 1950s (Figure 8). ${ }^{66}$ Pleuromutilin and its derivatives bind to the peptidyl transferase center of bacterial ribosomes, which are intrinsically different from human ribosomes, and hence selectively inhibit bacterial protein syntheses. ${ }^{67}$ Naturally occurring pleuromutilin displays moderate activity against Gram-positive bacterial strains, and it was demonstrated that this activity could be enhanced by semi-synthetic modifications to the natural product, especially the C-14 glycolate ester. ${ }^{68}$ Currently, there are three pleuromutilin antibiotics on the market: retapamulin (128), indicated for skin infection (the first pleuromutilin derivative approved for human use), tiamulin (129), and valnemulin (130), two veterinary drugs. ${ }^{69}$ Unfortunately, the development of pleuromutilin and its relatives has been limited by their metabolic instability, with the C-2 and C- 8 methylenes being rapidly hydroxylated in vivo by cytochrome P450 enzymes, particularly CYP3A4. ${ }^{69}$

X-ray analysis (Figure 9) of the complexes between bacterial ribosomes and active pleuromutilin compounds has revealed their mode of binding, with key interactions arising from (1) the hydrogen bonds from the C-3 ketone of the cyclopentanone moiety, the carbonyl of the C-14 glycolate or thioglycolate ester, and the C-11 hydroxyl group on the 8-membered ring; and (2) van der Waals contact between the alicyclic portions of the pleuromutilins and hydrophobic portions of the ribosomes. ${ }^{70}$ Using this insight, 
we envisioned that chemical synthesis could be leveraged to produce unnatural pleuromutilin analogues that might be stable to metabolism while retaining or enhancing potency and maintaining its exquisite selectivity for the bacterial ribosome.
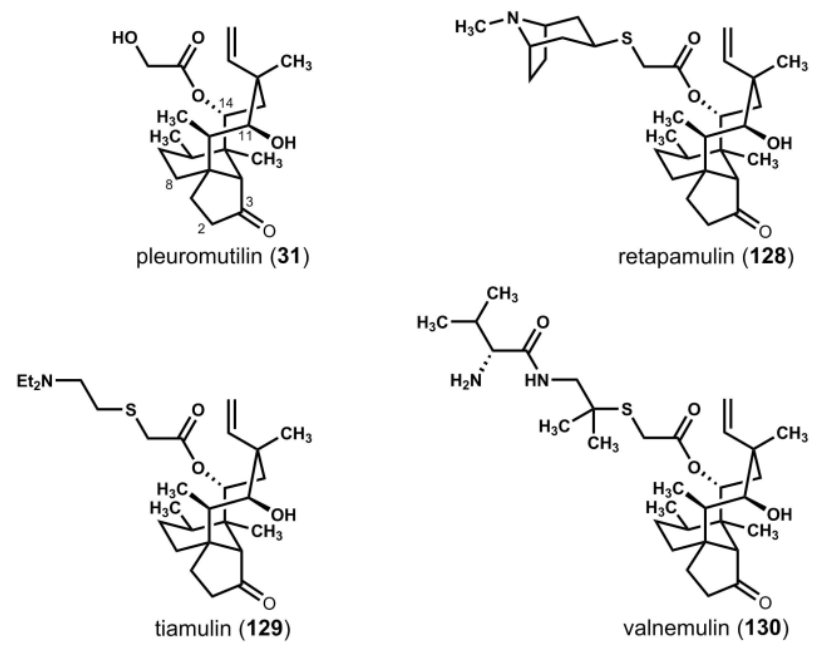

Figure 8. Pleuromutilin and its derivatives.
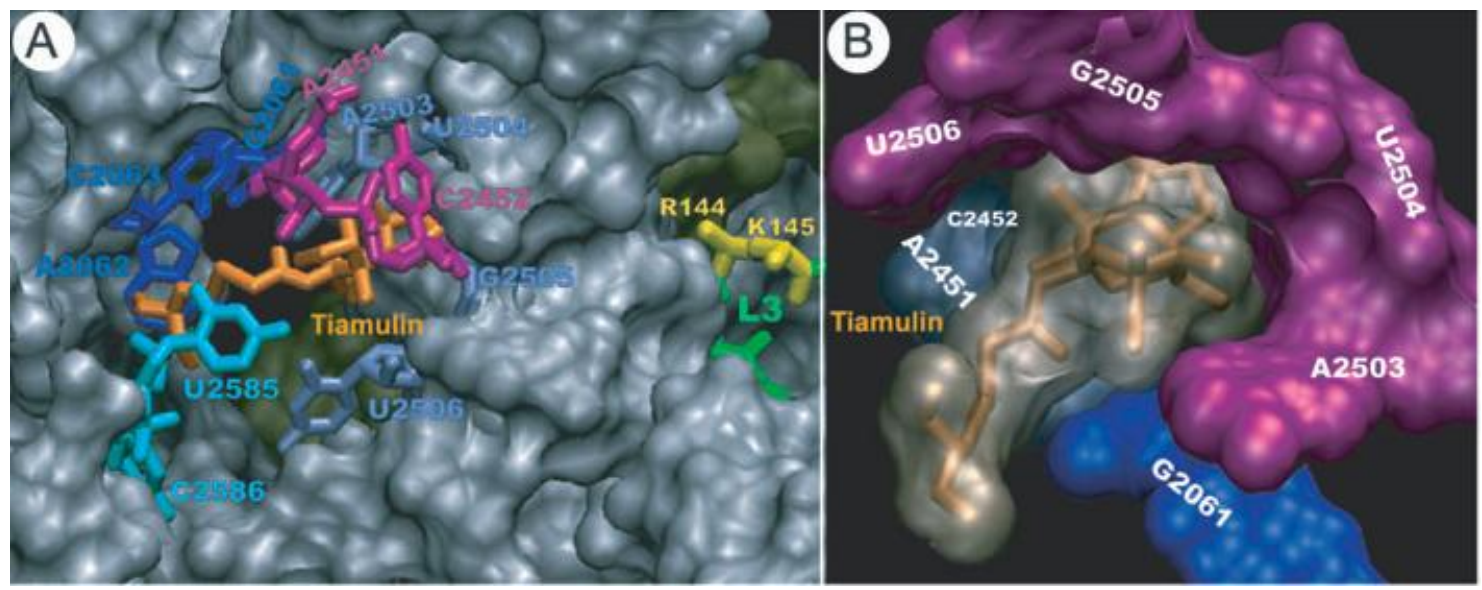

Figure 9. Structure of tiamulin within the peptidyl transferase center (PTC) (Copyright 2004 Blackwell Publishing Ltd). ${ }^{70 a}$

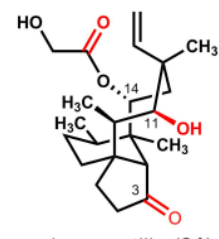

pleuromutilin (31)
VS.

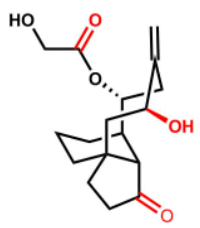

targeted scaffold (131)

Figure 10. Targeted pleuromutilin-like scaffold.

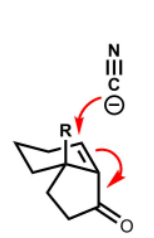

132

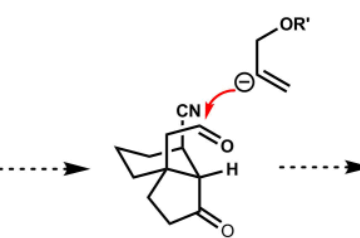

133

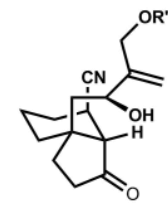

134

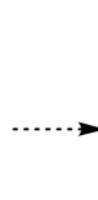

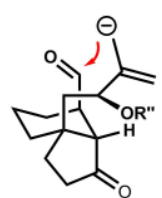

135

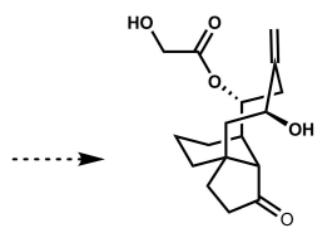

targeted scaffold (131)

Scheme 14. Synthetic strategies towards targeted pleuromutilin derivatives.

The pleuromutilin scaffold is readily available from biosynthetic fermentation ${ }^{71}$ and has traditionally served as a practical starting point for many successful semi-synthesis efforts, complementing the fully synthetic approaches explored 
contemporaneously by several groups. ${ }^{72}$ We recognized the extreme difficulty semi-synthetic approaches faced to chemically modify certain portions of the pleuromutilin skeleton, particularly the metabolically labile C- 8 methylene and, taking inspiration from the binding mode observed by X-ray analysis, ${ }^{70}$ we were inspired by the potential activity of simplified scaffolds like $\mathbf{1 3 1}$ (Figure 10) compared to the more heavily-substituted natural pleuromutilin 31. The proposed synthetic scaffold would maintain all the key elements for hydrogen bonding, previously proven necessary for activity, but the absence of most other functionality was proposed to add flexibility to the synthetic design process and, hopefully, lessen metabolic instability. The planned synthetic strategy called for a diastereoselective conjugate addition of cyanide to enone 132, giving cis-hydrindanone intermediate $\mathbf{1 3 3}$ (Scheme 14). Addition of an alkenyl anion equivalent to the aldehyde would furnish allylic alcohol 134. The aldehyde derived from selective reduction of the nitrile would then be subjected to an intramolecular allyl addition to yield $\mathbf{1 3 1} .^{73}$

As expected, $\mathbf{1 3 7}$ was available from a diastereoselective cyanide addition to $\mathbf{1 3 6}$ followed by acetal formation with ethylene glycol (Scheme 15). After ozonolysis of the terminal olefin, the resulting aldehyde was coupled with related vinyl halides $\mathbf{1 3 8}$ via Nozaki-Hiyama-Kishi reaction, giving rise to separable epimeric alcohols 139a and 139b. Epimers 139a and 139b were advanced to epimeric products $\mathbf{1 4 0 a}$ and $\mathbf{1 4 0 b}$, which, upon treatment with chromium(II) chloride, could be converted to the diastereomeric 141a-d, each containing the desired 8-membered ring. Interestingly, substrate 140a participates in this ring closure much more rapidly than its epimer, 140b. Indeed, 140a smoothly underwent the chromium-mediated ring formation regardless of the protecting group on the C-11 oxygen, while 140b was much more sensitive to the steric environment at this position, further emphasizing the large effect of this subtle difference. This approach was used for the successful construction of several novel pleuromutilin-like scaffolds. $^{73}$

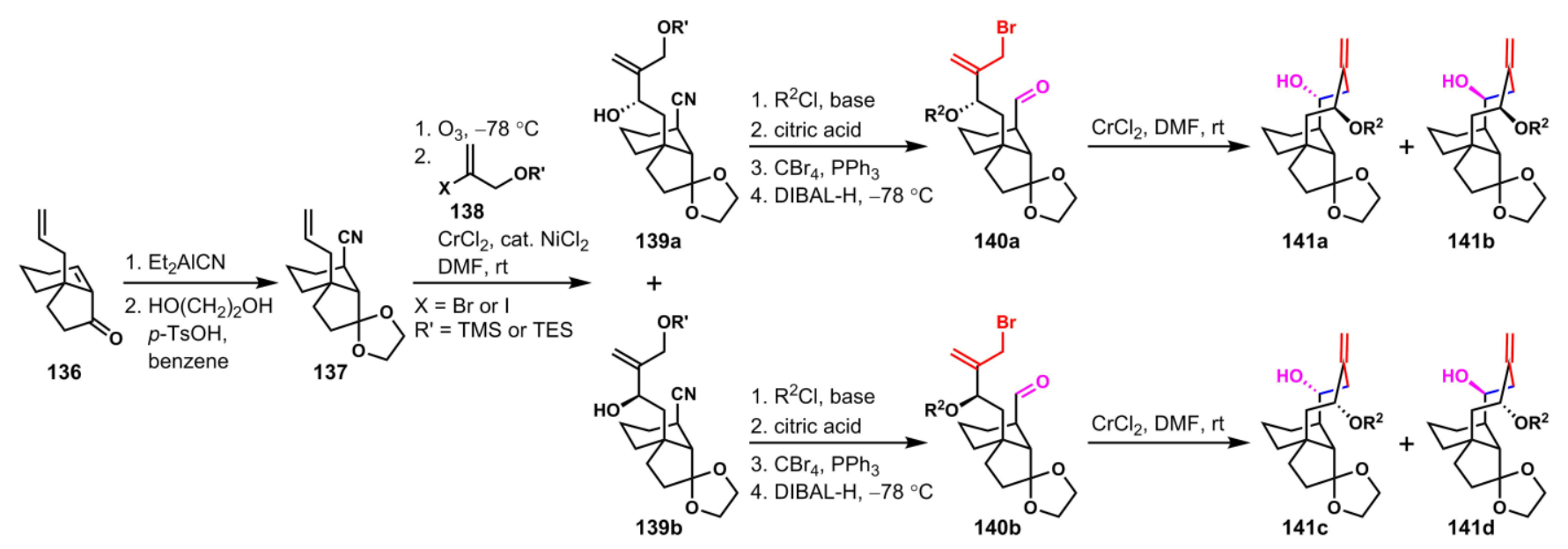

Scheme 15. New pleuromutilin scaffolds are available via de novo chemical synthesis. para-TsOH = para-toluenesulfonic acid monohydrate; TMS = trimethylsilyl; TES = triethylsilyl; DIBAL-H = diisobutylaluminum hydride; DMF = N,N-dimethylformamide. 


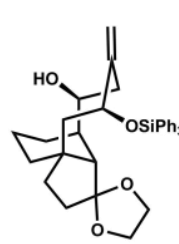

$142 b$

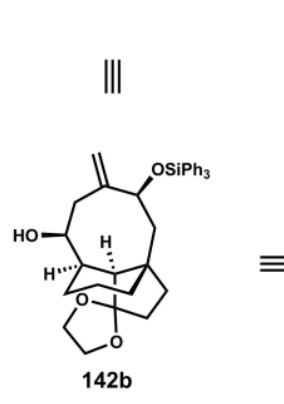

$142 b$
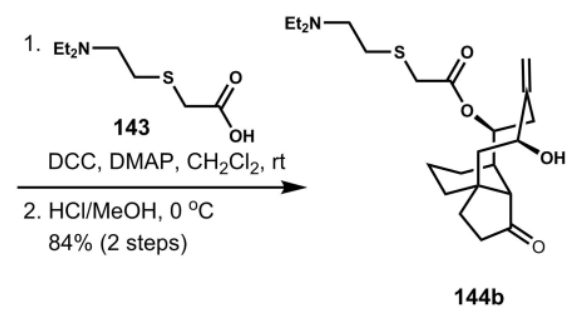

$144 b$

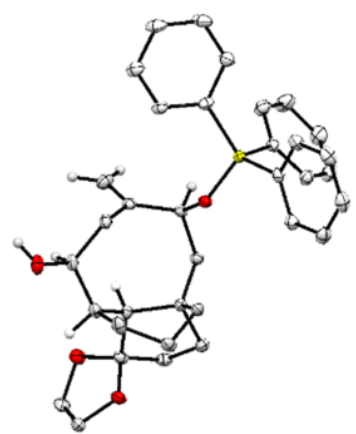

Scheme 16. A representative pleuromutilin-like compound (X-ray crystallographic data for compounds $\mathbf{1 4 2 b}$ have been deposited at the Cambridge Crystallographic Data Centre under the number CCDC 861251). DCC $=N, N$ ’-dicyclohexylcarbodiimide;

DMAP = 4-dimethylaminopyridine.

Rapid diversification of these intermediates was achieved through the incorporation of various side-chains at the C-14 position, with a global deprotection affording the desired pleuromutilin analogues, such as $\mathbf{1 4 4 b}$ (Scheme 16). It was found that removal of the hydrophobic substituents on the pleuromutilin-like compounds greatly improved their metabolic stability to cytochrome P450 enzymes but came at the cost of decreased antimicrobial activity, typified by the activities of both 144b and its C-14 epimer which were found to be significantly lower than tiamulin (129, Figure 8) against several panels of Gram-positive and Gram-negative bacteria. $^{74}$ Some of these synthetic pleuromutilin-like compounds did demonstrate moderate activity against an attenuated strain of Mtb $m c^{2} 7000$, however, it was later found that these same compounds are inactive against a pathogenic tuberculosis strain, in laboratories affiliated with the $T B$ Alliance. Unfortunately, it was also found that reducing the alkene substituent at $\mathrm{C}-12$ to a sp ${ }^{3}$ carbon (in an effort to better model the naturally occurring substitution present in the pleuromutilin carbon framework) resulted in no increased antibacterial activity. Apparently, there exists a tradeoff between suppressing metabolic susceptibility and maintaining antibacterial activity, a postulated balance tied to the presence of hydrophobic groups on the pleuromutilin scaffold, but whose exact mechanism is currently unknown. We hope to apply these lessons towards the production of new, de novo synthetic scaffolds to access potent and metabolically stable pleuromutilin analogues. ${ }^{75}$
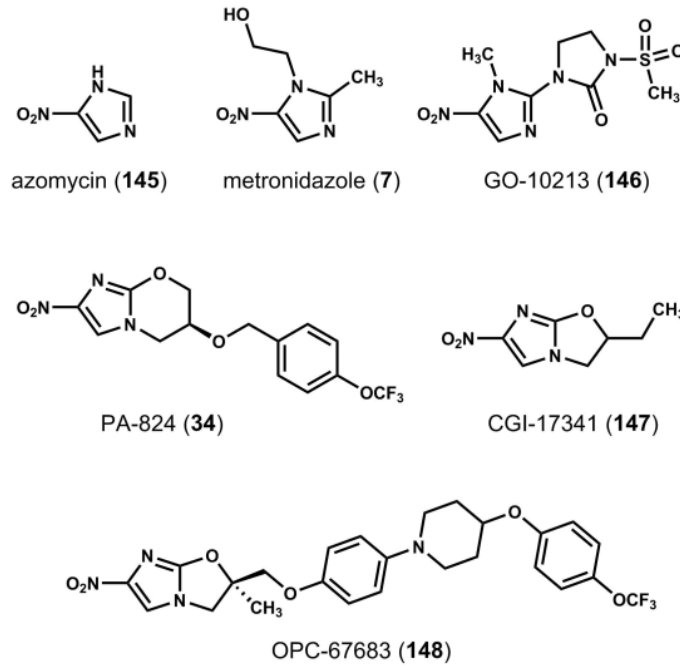
Figure 11. Representative nitroimidazole antibiotics.

\section{Improved synthesis of PA-824}

Nitroimidazole compounds have a long history of use as effective antibiotics (Figure 11 ) ${ }^{76}$ Such compounds are prodrugs, only toxic once activated by bacterial redox systems in vivo, leading to fatal DNA damage through the action of unstable radical intermediates. Their success can be understood to arise from two main factors: a constant influx of the compound due to the concentration imbalance resulting from constant reduction of nitroimidazoles within the cell membrane ${ }^{77 a}$ and excellent selectivity for bacteria (and other microorganisms) as the highly-reducing $\mathrm{Fe}^{\mathrm{II}}$ ferredoxin required for their reduction is not present in the mammalian redox system. ${ }^{77 b}$ Finally, in contrast to several other traditional antibacterial classes whose levels of efficacy are only useful for bacteria with high replication rates, nitroimidazole compounds show promising complementary activity against dormant or slow-growing organisms, such as M. tuberculosis. ${ }^{78}$

PA-824 (34), a synthetic, bicyclic nitroimidazole anti-tuberculosis compound developed under the generic name pretomanid by $T B$ Alliance, was discovered in $2000 .{ }^{79}$ Previous synthetic approaches to PA-824 (34) started with explosive dinitroimidazole 149 and expensive epoxide 150, and a synthetic sequence requiring a throughput-limiting four further chromatographic separations (Scheme 17). ${ }^{80}$ To reduce the cost and increase the availability of PA-824 (34), as well as circumvent the safety issues surrounding dinitroimidazole 149, we realized that a new approach would be needed. To avoid the costly and dangerous intermediates utilized previously, the new approach would construct the 6-memberd oxazine ring from the non-explosive nitroimidazole scaffold 152 and a functionalized glycidol derivative $\mathbf{1 5 3} .^{81}$

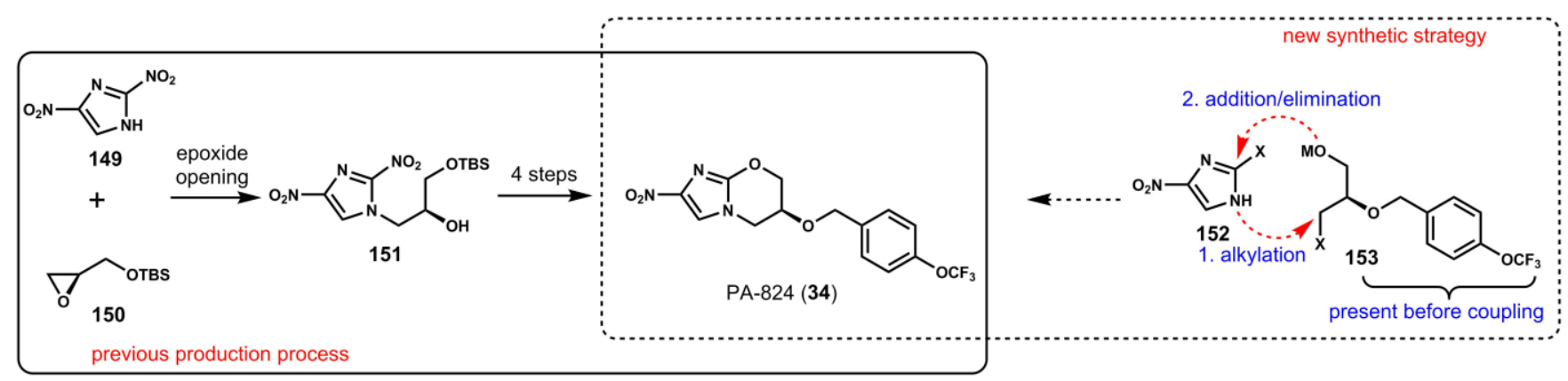

Scheme 17. Synthetic strategies towards PA-824. TBS = tert-butyldimethylsilyl. 


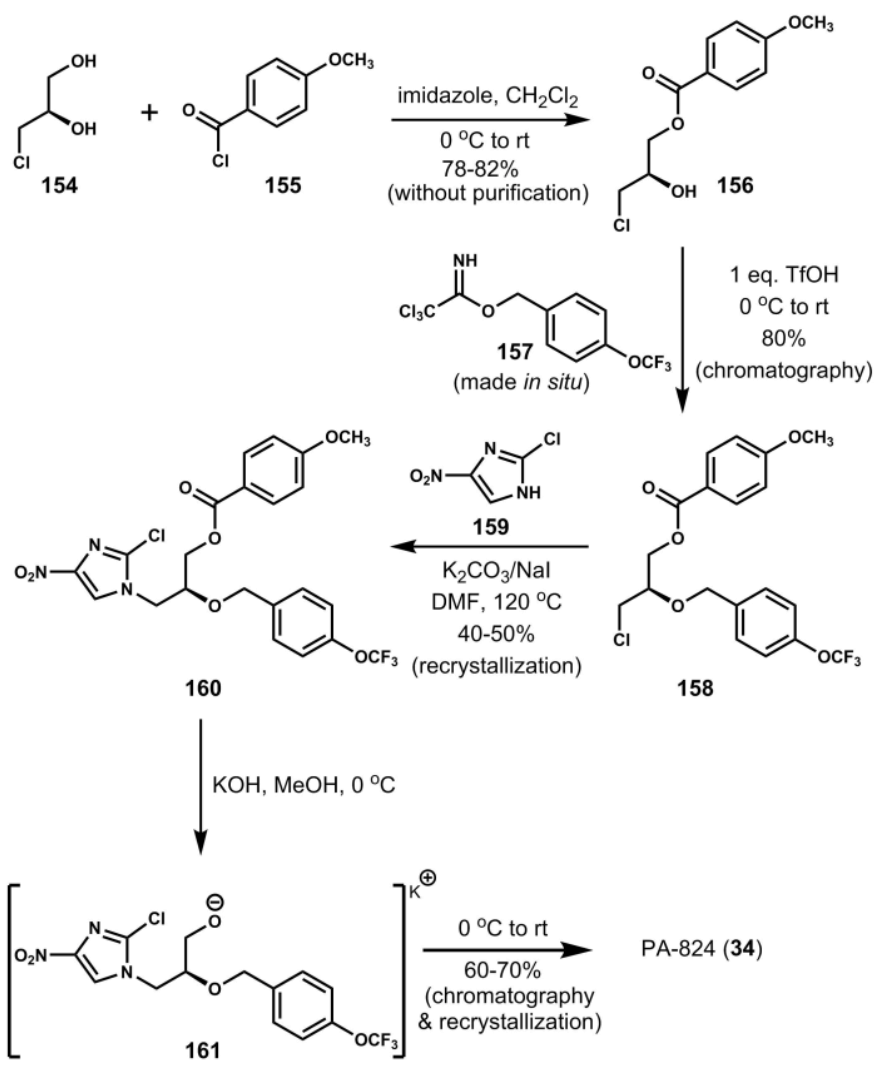

Scheme 18. Improved synthetic route for production of PA-824. TfOH = trifluoromethanesulfonic acid;

$\mathrm{DMF}=N, N$-dimethylformamide.

Importantly, synthesis of pseudosymmetrical glycidol derivative 153 starts from readily available diol 154 (Scheme 18). After acylation of the primary alcohol of $\mathbf{1 5 4}$ and benzylation of the secondary alcohol, the resulting alkyl chloride $\mathbf{1 5 8}$ can be coupled with commercially available, non-explosive nitroimidazole 159, giving rise to 160 . Treatment of 160 with potassium hydroxide in methanol triggers a saponification/anionic cyclization/elimination sequence to furnish PA-824 (34) in good yield, on gram-scale, and with retention of the absolute configuration. The whole process from 154 to 34 only required two (opposed to the previously required four) chromatographic separations and two recrystallizations. This improved approach simplifies the synthetic process and provides a means for the large-scale production of PA-824 (34) for further studies ${ }^{81}$ showing yet another instance where chemical synthesis can have a large impact in the pursuit of anti-microbials.

\section{Conclusion}

In this article, we revisited the chemical concepts underlying our syntheses of the promising antibacterial natural products abyssomicin $\mathrm{C}$ and guanacastepene $\mathrm{E}$, our reassignment of the structure of the M. tuberculosis metabolite edaxadiene, our construction of several hirsutellone-like compounds, our effort to expand the depth and diversity of the pleuromutilin class of antibiotics by de novo chemical synthesis, and our short, scalable synthesis of the promising new antitubercular agent PA-824. While future research is needed to establish the therapeutic potentials of these particular classes of anti-infective agents, the ideas and methods of organic chemical synthesis will unquestionably be central to new efforts to combat the global threat posed by pathogenic bacteria through the development of new chemotypes for antibiotic development efforts.

\section{Author Information}


Junjia Liu received his Bachelor of Science degree in Chemistry from Fudan University in 2006. He then pursued graduate studies at Princeton University, where he earned his Master's degree in 2008 and his Ph.D. in 2012. Under the direction of Professor Erik Sorensen, he conducted research in the fields of natural product synthesis, synthetic methodology and medicinal chemistry. His broad research interests include organic chemistry, chemical biology, materials and polymer science, and chemical education. He is currently a research scientist at Eastman Chemical Company.

T. Aaron Bedell received his Bachelor of Science degree in Chemistry from the University of Minnesota-Twin Cities in 2010, where he pursued undergraduate research under the direction of Professor Thomas R. Hoye. He is currently pursuing graduate studies at Princeton University in the Sorensen lab, having earned his Master's degree in 2012. His current research focuses on the application and development of new chemical methods for the direct functionalization of $\mathrm{C}-\mathrm{H}$ bonds in collaboration with the NSF CCI Center for Selective C-H Functionalization.

Julian G. West received his Bachelor of Science (Honours) degree in Chemistry from the University of British Columbia (Vancouver) in 2013, where he pursued undergraduate research under the direction of Professor Glenn M. Sammis. Having earned his master's degree in 2014 under Professor Sorensen at Princeton University, he is currently pursuing his PhD as a NSF Graduate Research Fellow in the same lab. Julian's research interests comprise the design of bio-inspired catalyst systems for the activation of $\mathrm{C}-\mathrm{H}$ bonds and he is currently collaborating with the NSF CCI Center for Selective $\mathrm{C}-\mathrm{H}$ Functionalization towards realizing this.

Erik J. Sorensen received his Bachelor of Arts degree in Chemistry from Syracuse University and began his graduate studies in chemical synthesis at the University of California, San Diego in 1989. Under the direction of Professor K. C. Nicolaou, he contributed to a laboratory synthesis of the cancer drug Taxol, co-authored Classics in Total Synthesis, and obtained his Ph.D. in 1995. After completing an NSF postdoctoral fellowship with Professor Samuel Danishefsky, he started his independent career at The Scripps Research Institute in 1997. In 2003, he moved his research group to Princeton University where he is the Arthur Allan Patchett Professor in Organic Chemistry.

* Corresponding Author

Fax: +1-608-258-1980; Tel: +1-609-258-8135; E-mail: ejs@ princeton.edu

${ }^{\S}$ Present address: Eastman Chemical Company, P.O. Box 1972, Kingsport, TN 37662, USA.

\section{Acknowledgement}

We gratefully acknowledge financial support from the Grand Challenges Initiative at Princeton University and from the National Institute of General Medical Sciences (R01 GM065483), and financial support (J.L.) from Eli Lilly and from BristolMyers Squibb and financial support (J.G.W.) from the National Science Foundation (DGE 1148900). We sincerely thank Dr Matthew A. Schiffler at Eli Lilly for useful discussions and for helping edit the manuscript.

\section{References}

1 Fischbach, M. A.; Walsh, C. T. Science 2009, 325, 1089-1093.

2 (a) Wenzel, R. P. N. Engl. J. Med. 2004, 351, 523-526; (b) Cooper, M. A.; Shlaes, D. Nature 2011, 472, 32. 
3 (a) Costerton, J. W.; Stewart, P. S.; Greenberg, E. P. Science 1999, 284, 1318-1322; (b) Stewart, P. S.; Costerton, J. W. Lancet 2001, 358, 135-138; (c) Brüssow, H, Canchaya, C.; Hardt, W. Microbiol. Mol. Biol. Rev. 2004, 68, 560-602; (d) Wiedenbeck, J.; Cohan, F. M. FEMS Microbiol. Rev. 2011, 35, 957-976; (e) Tenover, F. C. Am. J. Med. 2006, 119, S3-S10.

4 Taubes, G. Science 2008, 321, 356-361.

5 (a) Sacchettini, J. C.; Rubin, E. J.; Freundlich, J. S. Nat. Rev. Microbiol. 2008, 6, 41-52; (b) Koul, A.; Arnoult, E.; Lounis, N.; Guillemont, J.; Andries, K. Nature 2011, 469, 483-490.

6 (a) Brzuszkiewicz, E.; Thürmer, A.; Schuldes, J.; Leimbach, A.; Liesegang, H.; Meyer, F.; Boelter, J.; Petersen, H.; Gottschalk, G.; Daniel, R. Arch. Microbiol. 2011, 193, 883-891; (b) Frank, C.; Werber, D.; Cramer, J. P.; Askar, M.; Faber, M.; an der Heiden, M.; Bernard, H.; Fruth, A.; Prager, R.; Spode, A.; Wadl, M.; Zoufaly, A.; Jordan, S.; Kemper, M. J.; Follin, P.; Müller, L.; King, L. A.; Rosner, B.; Buchholz, U.; Stark, K.; Krause, G. N. Engl. J. Med. 2011, 365, 1771-1781; (c) Safdar, N.; Said, A.; Gangnon, R. E.; Maki, D. G. J. Am. Med. Ass. 2002, 288, 996-1001; (d) Wong, C. S.; Jelacic, S.; Habeeb, R. L.; Watkins, S. L.; Tarr, P. I. N. Engl. J. Med. 2000, 342, 1930-1936.

7 Appelbaum, P. C. Int. J. Antimicrob. Agents 2007, 30, 398-408.

8 Nathan, C. Nature 2004, 431, 899-902.

9 Payne, J.C.; Gwynn, M.N.; Holmes, D.J.; Pompliano, D.L. Nature Rev. Drug. Discov. 2007, 6, 29-40.

10 (a) Nathan, C. Goldberg, F. M. Nat. Rev. Drug Discov. 2005, 4, 887-891; (b) Chantziaras, I.; Boyen, F.; Callens, B.; Dewulf, J. J. Antimicrob. Chemother. 2014, 69, 827-834; (c) Exec. Order No. 13676, 79 C.F.R. 56931-56935 (2014); (d) Van Boeckel, T. P; Brower, C.; Gilbert, M.; Grenfell, B. T.; Levin, S. A.; Robinson, T. P.; Teillant, A.; Laxminarayan, R. Proc. Natl. Acad. Sci. U.S.A. 2015, 112, 5649-5654.

11 (a) Cragg, G. M.; Newman, D. J.; Snader, K. M. J. Nat. Prod. 1997, 60, 52-60; (b) Newman, D. J.; Cragg, G. M.; Snader, K. M. J. Nat. Prod. 2003, 66, 1022-1037; (c) Newman, D. J.; Cragg, G. M. J. Nat. Prod. 2007, 70, 461-477; (d) Peláez, F. Biochem. Pharmacol. 2006, 71, 981-990.

12 Paul, S. M.; Mytelka, D. S.; Dunwiddie, C. T.; Persinger, C. C.; Munos, B. H.; Lindborg, S. R.; Schacht, A. L. Nat. Rev. Drug Discov. 2010, 9, 203-214.

13 Cook, A. H. Q. Rev. Chem. Soc. 1948, 2, 203-259.

14 Jones, R. N. Diagn. Microbiol. Infect. Dis. 1989, 12, 25-31.

15 Hooper, D. C.; Wolfson, J. S. Rev. Infect. Dis. 1989, 11, S902-S911.

16 Berry, M. Q. Rev. Chem. Soc. 1963, 17, 343-361.

17 Chopra, I.; Roberts, M. Microbiol. Mol. Biol. Rev. 2001, 65, 232-260.

18 Hermann, T. Cell. Mol. Life Sci. 2007, 64, 1841-1852.

19 Hamad, B. Nat. Rev. Drug Discov. 2010, 9, 675-676.

20 (a) Sutherland, R.; Boon, R. J.; Griffin, K. E.; Masters, P. J.; Slocombe, B; White, A. R. Antimicrob. Agents Chemother. 1985, 27, 495-498; (b) Class, Y. J.; DeShong, P. Chem. Rev. 1995, 95, 1843-1857.

21 (a) Müller, M.; Schimz, K. Cell. Mol. Life Sci. 1999, 56, 280-285; (b) Zurenko, G. E.; Gibson, J. K.; Shinabarger, D. L.; Aristoff, P. A.; Ford, C. W.; Tarpley, W. G. Curr. Opin. Pharmacol. 2001, 1, 470-476.

22 Baltz, R. H.; Miao, V.; Wrigley, S. K. Nat. Prod. Rep. 2005, 22, 717-741. 
23 (a) Häbich, D.; von Nussbaum, F. ChemMedChem 2006, 1, 951; (b) Saleem, M.; Hussain, H.; Ahmed, I.; van Ree, T.; Krohn, K. Nat. Prod. Rep. 2011, 28, 1534-1579; (c) Zhang, C.; Ondeyka, J.; Herath, K.; Jayasuriya, H.; Guan, Z.; Zink, D. L.; Dietrich, L.; Burgess, B.; Ha, S. N.; Wang, J.; Singh, S. B. J. Nat. Prod. 2011, 74, 329-340.

24 Butler, M. S.; Cooper, M. A. J. Antibiot. 2011, 64, 413-425.

25 Woodford, N.; Ellington, M. J. Clin. Microbiol. Infect. 2007, 13, 5-18.

26 Payne, D. J.; Gwynn, M. N.; Holmes, D. J.; Pompliano, D. L. Nat. Rev. Drug Discov. 2007, 6, 29-40.

27 Walsh, C. T. Nat. Rev. Microbiol. 2003, 1, 65-70.

28 (a) Charest, M. G.; Lerner, C. D.; Brubaker, J. D.; Siegel, D. R.; Myers, A. G. Science 2005, 308, 395-398; (b) Sun, C.; Wang, Q.; Brubaker, J. D.; Wright, P. M.; Lerner, C. D.; Noson, K.; Charest, M.; Siegel, D. R.; Wang, Y.; Myers, A. G. J. Am. Chem. Soc. 2008, 130, 17913-17927.

29 (a) Clardy, J.; Fischbach, M. A.; Walsh, C. T. Nat. Nanotechnol. 2006, 24, 1541-1550; (b) Butler, M. S.; Buss, A. D. Biochem. Pharmacol. 2006, 71, 919-929.

30 (a) Bister, B.; Bischoff, D.; Ströbele, M.; Riedlinger, J.; Reicke, A.; Wolter, F.; Bull, A. T.; Zähner, H.; Fiedler, H.; Süs smuth, R. D. Angew. Chem. Int. Ed. 2004, 43, 2574-2576; (b) Riedlinger, J.; Reicke, A.; Zähner, H.; Krismer, B.; Bull, A. T.; Maldonado, L. A.; Ward, A. C.; Goodfellow, M.; Bister, B.; Bischoff, D.; Süssmuth, R. D.; Fiedler, H. J. Antibiot. 2004, 57, $271-279$.

31 Bermingham, A.; Derrick, J. P. BioEssays 2002, 24, 637-648.

32 (a) Niu, X.; Li, S.; Görls, H.; Schollmeyer, D.; Hilliger, M.; Grabley, S.; Sattler, I. Org. Lett. 2007, 9, 2437-2440; (b) Igarashi, Y.; Yu, L.; Miyanaga, S.; Fukuda, T.; Saitoh, T.; Sakurai, H.; Saiki, I.; Alonso-Vega, P.; Trujillo, M. E. J. Nat. Prod. 2010, 73, 1943-1946.

33 For total syntheses and synthetic studies towards abyssomicins, see: (a) Rath, J.; Eipert, M.; Kinast, S.; Maier, M. E. Synlett 2005, 314-318; (b) Rath, J.; Kinast, S.; Maier, M. E. Org. Lett. 2005, 7, 3089-3092; (c) Zografos, A. L.; Yiotakis, A.; Georgiadis, D. Org. Lett. 2005, 7, 4515-4518; (d) Sinder, B. B.; Zou, Y.; Org. Lett. 2005, 7, 4939-4941; (e) Couladouros, E. A.; Bouzas, E. A.; Magos, A. D. Tetrahedron 2006, 62, 5272-5279; (f) Nicolaou, K. C.; Harrison, S. T. Angew. Chen. In. Ed. 2006, 45, 3256-3260; (g) Nicolaou, K. C.; Harrison, S. T. J. Am. Chem. Soc. 2007, 129, 429-440; (h) Nicolaou, K. C.; Harrison, S. T.; Chen, J. S. Synthesis 2009, 33-42.

34 (a) Lynen, F. Pure Appl. Chem. 1967, 14, 137-168; (b) Clardy, J.; Walsh, C. T. Nature 2004, 432, 829-837; (c) Fischbach, M. A.; Clardy, J. Nat. Chem. Biol. 2007, 3, 353-355; (d) Neumann, C. S.; Fujimori, D. G.; Walsh, C. T. Chem. Biol. 2008, 15, 99-109.

35 (a) Diels, O.; Alder, K. Justus Liebigs Ann. Chem. 1928, 460, 98-122; (b) Corey, E. J. Angew. Chem. Int. Ed. 2002, 41, 16501667; (c) Nicolaou, K. C.; Snyder, S. A.; Montagnon, T.; Vassilikogiannakis, G. Angew. Chem. In. Ed. 2002, 41, $1668-1698$.

36 (a) Stocking, E. M.; Williams, R. M. Angew. Chem. Int. Ed. 2003, 42, 3078-3115; (b) Kelly, W. L. Org. Biomol. Chem. 2008, 6, 4483-4493; (c) Liu, L.; Li, Y.; Li, L.; Guo, L.; Liu, G.; Che, Y. J. Org. Chem. 2013, 78, 2992-3000.

37 Zapf, C. W.; Harrison, B. A.; Drahl, C.; Sorensen E. J. Angew. Chem. Int. Ed. 2005, 44, 6533-6537.

38 Keller, S.; Nicholson, G.; Drahl, C.; Sorensen, E.; Fiedler, H.; Süssmuth, R. D. J. Antibiot. 2007, 60, $391-394$.

39 Gottardi, E. M.; Krawczyk, J. M.; von Suchodoletz, H.; Schadt, S.; Mühlenweg, A.; Uguru, G. C.; Pelzer, S.; Fiedler, H.; Bibb, M. J.; Stach, J. E. M.; Süssmuth, R. D. ChemBioChem 2011, 12, 1401-1410.

40 Freundlich, J. S.; Lalgondar, M.; Wei, J.; Swanson, S.; Sorensen, E. J.; Rubin, E. J.; Sacchettini, J. C. Tuberculosis 2010, 90 , 298-300.

41 Keller, S.; Schadt, H. S.; Ortel, I.; Süssmuth, R. D. Angew. Chem. Int. Ed. 2007, 46, 8284-8286. 
42 (a) Brady, S. F.; Singh, M. P.; Janso, J. E.; Clardy, J. J. Am. Chem. Soc. 2000, 122, 2116-2117; (b) Singh, M. P.; Janso, J. E.; Luckman, S. W.; Brady, S. F.; Clardy, J.; Greenstein, M.; Maiese, W. M. J. Antibiot. 2000, 53, 256-261; (c) Brady, S. F.; Bondi, S. M.; Clardy, J. J. Am. Chem. Soc. 2001, 123, 9900-9901.

43 For a review of totally syntheses and synthetic studies towards guanacastepenes, see: (a) Maifeld, S. V.; Lee, D. Synlett 2006, 1623-1644; for other recent works, see: (b) Iimura, S.; Overman, L. E.; Paulini, R.; Zakarian, A. J. Am. Chem. Soc. 2006, 128, 13095-13101; (c) Miller, A. K.; Hughes, C. C.; Kennedy-Smith, J. J.; Gradl, S. N.; Trauner, D. J. Am. Chem. Soc. 2006, 128, 17057-17062; (d) Li, C.; Wang, C.; Liang, B.; Zhang, X.; Deng, L.; Liang, S.; Chen, J.; Wu, Y.; Yang, Z. J. Org. Chem. 2006, 71, 6892-6897; (e) McGowan, C. A.; Schmieder, A. K.; Roberts, L.; Greaney, M. F. Org. Biomol. Chem. 2007, 5, 1522-1524; (f) Michalak, K.; Michalak, M.; Wicha, J. Tetrahedron Lett. 2008, 49, 6807-6809; (g) Michalak, K.; Michalak, M.; Wicha, J. Tetrahedron Lett. 2010, 51, 4344-4346; (h) Oonishi, Y.; Taniuchi, A.; Sato, Y. Synthesis 2010, 2884-2892; (i) Michalak, K.; Michalak, M.; Wicha, J. J. Org. Chem. 2010, 75, 8337-8350; (j) Gampe, C. M.; Carreira, E. M. Angew. Chem. Int. Ed. 2011, 50, 2962-2965.

44 (a) Norin, T. Acta Chem. Scand. 1963, 17, 738-748; (b) Norin, T, Acta Chem. Scand. 1965, 19, 1289-1292; (c) Dauben, W. G.; Deviny, E. J. J. Org. Chem. 1966, 31, 3794-3798.

45 (a) Baker, W. R.; Senter, P. D.; Coates, R. M. J. Chem. Soc. Chem. Comm. 1980, 21, 1011-1012; (b) Comins, D. L.; Zhang, Y.; Zheng, X. Chem. Comm. 1998, 2509-2510; (c) Comins, D. L.; Zheng, X.; Coehring, R. R. Org. Lett. 2002, 4, $1611-1613$.

46 (a) Shipe, W. D.; Sorensen, E. J. Org. Lett. 2002, 4, 2063-2066; (b) Shipe, W. D.; W. D.; Sorensen, E. J. J. Am. Chem. Soc. 2006, $128,7025-7035$.

47 Kinchen, J. M.; Ravichandran, K. S. Nat. Rev. Mol. Cell Biol. 2008, 9, 781-795.

48 Deretic, V.; Singh, S.; Master. S.; Harris, J.; Roberts, E.; Kyei, G.; Davis, A.; de Haro, S.; Naylor, J.; Lee, H.; Vergne, I. Cell. Microbiol. 2006, 8, 719-727.

49 (a) Mann, F. M.; Xu, M.; Chen, X.; Fulton, D. B.; Russell, D. G.; Peters, R. J. J. Am. Chem. Soc. 2009, 131, 17526-17527; (b) Mann. F. M.; Prisic, S.; Hu, H.; Xu, M.; Coates, R. M.; Peters, R. J. J. Biol. Chem. 2009, 284, 23574-23579.

50 (a) Pethe, K.; Swenson, D. L.; Alonso, S.; Anderson, J.; Wang, C.; Russell, D. G. Proc. Natl. Acad. Sci. U.S.A. 2004, 101, 13642-13647; (b) Mann, F. M.; Peters, R. J. Med. Chem. Commun. 2012, 3, 899-904.

51 Spangler, J. E.; Carson, C. A.; Sorensen, E. J. Chem. Sci. 2010, 1, 202-205.

52 Snider, B. B.; Kiselgof, E. Y. Tetrahedron 1996, 52, 6073-6084.

53 Rudi, A.; Akini, M.; Gaydou, E. Kashman, Y. J. Nat. Prod. 2004, 67, 1932-1935.

54 (a) Nakano, C.; Sato, T.; Hoshino, T. Koryo, Terupen oyobi Seiyu Kagaku ni kansuru Toronkai Koen Yoshishu 2005, 49, 247249; (b) Nakano, C.; Okamura, T.; Sato, T.; Hara, T.; Dairi, T.; Toyomasu, T.; Sassa, T.; Hoshino, T. 48th Symp. Chem. Nat. Prod. 2006, 19-24. http://ci.nii.ac.jp/naid/110006682624/en

55 Maugel, N.; Mann, F. M.; Hillwig, M. L.; Peters, R. J.; Snider, B. B. Org. Lett. 2010, 12, 2626-2629.

56 For selected recent examples of structural revisions of natural products promoted by chemical synthesis, see: (a) Komano, K.; Shimamura, S.; Norizuku, Y.; Zhao, D.; Kabuto, C.; Sato, I.; Hirama, M. J. Am. Chem. Soc. 2009, 131, 12072-12073; (b) Wang, Z.; Min, S.; Danishefsky, S. J. J. Am. Chem. Soc. 2009, 131, 10848-10849; (c) Nicolaou, K. C.; Ortiz, A.; Zhang, H.; Guella, G. J. Am. Chem. Soc. 2010, 132, 7153-7176; (d) Gutekunst, W. R.; Baran, P. S. J. Am. Chem. Soc. 2011, 133, 19076-19079.

57 Isaka, M.; Rugseree, N.; Maithip, P.; Kongsaeree, P.; Prabpai, S.; Thebtaranonth, Y. Tetrahedron 2005, 61, 5577-5583; (b) Isaka, M.; Prathumpai, W.; Wongsa, P.; Tanticharoen, M. Org. Lett. 2006, 8, 2815-2817. 
58 He, H.; Yang, H. Y.; Bigelis, R.; Solum, E. H.; Greenstein, M.; Carter, G. T. Tetrahedron Lett. 2002, 43, $1633-1636$.

59 (a) Koizumi, F.; Hasegawa, A.; Ando, K.; Ogawa, T.; Hara, M. Jpn. Kokai Tokkyo, Koho 2001, JP 2001247574; (b) Hasegowa,

A.; Koizumi, F.; Takahashi, Y.; Ando, K.; Ogawa, T.; Hara, M.; Yoshida, M. 43rd Symp. Chem. Nat. Prod. 2001, 467-472. http://ci.nii.ac.jp/naid/110006682124/en

60 Nicolaou, K. C.; Härter, M. W.; Gunzner, J. L.; Nadin, A.; Liebigs Ann. Chem. 1997, 1283-1301.

61 For reviews, see: (a) Trost, B. M. Acc. Chem. Res. 1980, 13, 385-393; (b) Trost, B. M.; Van Vranken, D. L. Chem. Rev. 1996, 96, 395-422; (c) Trost, B. M.; Crawley, M. L.; Chem. Rev. 2003, 103, 2921-2943

62 Reber, K. P.; Tilley, S. D.; Sorensen, E. J. Chem. Soc. Rev. 2009, 38, 3022-3034.

63 (a) Tilley, S. D.; Reber, K. P.; Sorensen, E. J. Org. Lett. 2009, 11, 701-703; (b) Reber, K. P.; Tilley, S. D.; Carson, C. A.; Sorensen, E. J. J. Org. Chem. 2013, 78, 9584-9607.

64 For synthetic studies towards hirsutellones, GKK1032s and pyrrospirones, see: (a) Oikawa, H. J. Org. Chem. 2003, 68, 35523557; (b) Ui, H.; Omura, S.; Kuwajima, I. Synthesis 2005, 1691-1694; (c) Asano, M.; Inoue, M.; Watanabe, K.; Abe, H.; Katoh, T. J. Org. Chem. 2006, 71, 6942-6951; (d) Huang, M.; Huang, C.; Liu, B. Tetrahedron Lett. 2009, 50, 2797-2800; (e) Huang, M.; Song, L.; Liu, B. Org. Lett. 2010, 12, 2504-2507; (f) Halvorsen, G. T.; Roush, W. R. Tetrahedron Lett. 2011, 52, 2072-2075; (g) Uchiro, H.; Kato, R.; Sakuma, Y.; Takagi, Y.; Arai, Y.; Hasegawa, D. Tetrahedron Lett. 2011, 52, 6242-6245; (h) Nicolaou, K. C.; Sun, Y.; Sarlah, D.; Zhan, W.; Wu, T. R. Org. Lett. 2011, 13, 5708-5720.

65 (a) Nicolaou, K. C.; Sarlah, D.; Wu, T. R.; Zhan, W. Angew. Chem. In. Ed. 2009, 48, 6870-6874; (b) Uchiro, H.; Kato, R.; Arai, Y.; Hasegawa, M.; Kobayakawa, Y. Org. Lett. 2011, 13, 6268-6271.

66 Kavanagh, F.; Hervey, A; Robbins, W. Proc. Natl. Acad. Sci. U. S. A. 1951, 37, 570-574.

67 Högenauer, G. Eur. J. Biochem. 1975, 52, 93-98.

68 (a) Egger, H.; Reinshagen, H. J. Antibiot. 1976, 29, 915-922; (b) Egger, H.; H. Reinshagen, H. J. Antibiot. 1976, 29, 923-927; (c) Riedl, K. J. Antibiot. 1976, 29, 132-139; (d) Hunt, E. Drugs Fut. 2000, 25, 1163-1168.

69 (a) Phillips, O. A; Sharaf, L. H. Expert Opin. Ther. Patents 2007, 17, 429-435; (b) C. Hu and Y. Zou, Mini-Rev. Med. Chem. 2009, 9, 1397-1406; (c) Novak, R.; Shlaes, D. M. Curr. Opin. Invest. Drugs 2010, 11, 182-191; (d) Stresser, D. M.; Broudy, M. I.; Ho, T.; Cargill, C. E.; Blanchard, A. P.; Sharma, R.; Dandeneau, A. A.; Goodwin, J. J.; Turner, S. D.; Erve, J. C.; Patten, C. J.; Dehal, S. S.; Crespi, C. L. Drug Metab. Dispos. 2004, 32, 105-112.

70 (a) Schlünzen, F.; Pyetan, E.; Fucini, P.; Yonath, A.; Harms, J. M. Mol. Microbiol. 2004, 54, 1287-1294; (b) Davidovich, C.; Bashan, A.; Auerbach-Nevo, T.; Yaggie, R. D.; Gontarek, R. R.; Yonath, A. Proc. Natl. Acad. Sci. U. S. A. 2007, $104,4291-4296$.

71 F. Knauseder and E. Brandl, J. Antibiot. 1976, 29, 125-131.

72 For total syntheses and synthetic studies towards pleuromutilins, see: (a) M. Kahn, Tetrahedron Lett. 1980, 21, 4547-4548; (b) Gibbons, E. G. J. Org. Chem. 1980, 45, 1540-1541; (c) Gibbons, E. G. J. Am. Chem. Soc. 1982, 104, 1767-1769; (d) Paquette, L. A.; Bulman-Page, P. C. Tetrahedron Lett. 1985, 26, 1607-1610; (e) Paquette, L. A.; Wiedeman, P. E.; Bulman-Page, P. C. J. Org. Chem. 1988, 53, 1441-1450; (f) Paquette, L. A.; Bulman-Page, P. C.; Pansegrau, P. D.; Wiedeman, P. E. J. Org. Chem. 1988, 53, 1450-1460; (g) Paquette, L. A.; Pansegrau, P. D.; Wiedeman, P. E.; Springer, J. P. J. Org. Chem. 1988, 53, 1461-1466; (h) Boeckman, R. K. Jr.; Springer, D. M.; Alessi, T. R. J. Am. Chem. Soc. 1989, 111, 8284-8286; (i) Bacque, E.; Pautrat, F.; Zard, S. Org. Lett. 2003, 5, 325-328; (j) Helm, M. D.; Da Silva, M.; Sucunza, D.; Findley, T. J. K.; Procter, D. J. Angew. Chem. Int. Ed. 2009, 48, 9315-9317; (k) Findley, T. J. K.; Sucunza, D.; Miller, L. C.; Helm, M. D.; Helliwell, M.; Davies, D. T.; Procter, D. J. Org. Biomol. Chem. 2011, 9, 2433-2451; (1) Fazakerley, N. J.; Helm, M. D.; Procter, D. J. Chem. Eur. J. 2013, 19, 6718-6723. 
73 (a) Liu, L.; Lotesta, S. D.; Sorensen, E. J. Chem. Commun. 2011, 47, 1500-1502; (b) Lotesta, S. D.; Liu, J.; Yates, E. V.; Krieger, I.; Sacchettini, J. C.; Freundlich, J. S.; Sorensen, E.J. Chem. Sci. 2011, 2, 1258-1261.

74 (a) Unpublished results, Enzymatic data of metabolism from collaboration with Professor David H. Sherman at University of Michigan; (b) Unpublished results, Antibacterial data from collaboration with Pfizer, Novobiotic, and the TB Alliance.

75 For a recent review of total syntheses and synthetic studies towards pleuromutilins, see: Fazakerley, N. J.; Procter, E. J. Tetrahedron 2014, 70, 6911-6930.

76 Barry, C. E.; Boshoff, H. I. M.; Dowd, C. S. Curr. Pharm. Des. 2004, 10, 3239-3262.

77 (a) Edwards, D. I. J. Antimicrob. Chemother. 1993, 31, 9-20; (b) Samuelson, J. Antimicrob. Agents Chemother. 1999, 43, 15331541 .

78 (a) Wayne, L. G.; Sramek, H. A. Antimicrob. Agents Chemother. 1994, 38, 2054-2058; (b) Sun, Z.; Zhang, Y. Tuber. Lung Dis. 1999, 79, 319-320.

79 (a) Stover, C. K.; Warrener, P.; VanDevanter, D. R.; Sherman, D. R.; Arain, T. M.; Langhorne, M. H.; Anderson, S. W.; Towell, J. A.; Yuan, Y.; McMurray, D. N.; Kreiswirth, B. N.; Barry, C. E.; Baker, W. R. Nature 2000, 405, 962-966; (b) Ginsberg, A. M.; Laurenzi, M. W.; Rouse, D. J.; Whitney, K. D.; Spigelman, M. K. Antimicrob. Agents Chemother. 2009, 53, 3720-3725.

80 (a) Baker, W. R.; Shaopei, C.; Keeler, E. L. U.S. Patent 2000, \#6,087,358; (b) Orita, A.; Miwa, K.; Uehara, G.; Otera, J. Adv. Synth. Catal. 2007, 349, 2136-2144.

81 Marsini, M. A.; Reider, P. J.; Sorensen, E. J. J. Org. Chem. 2010, 75, 7479-7482. 


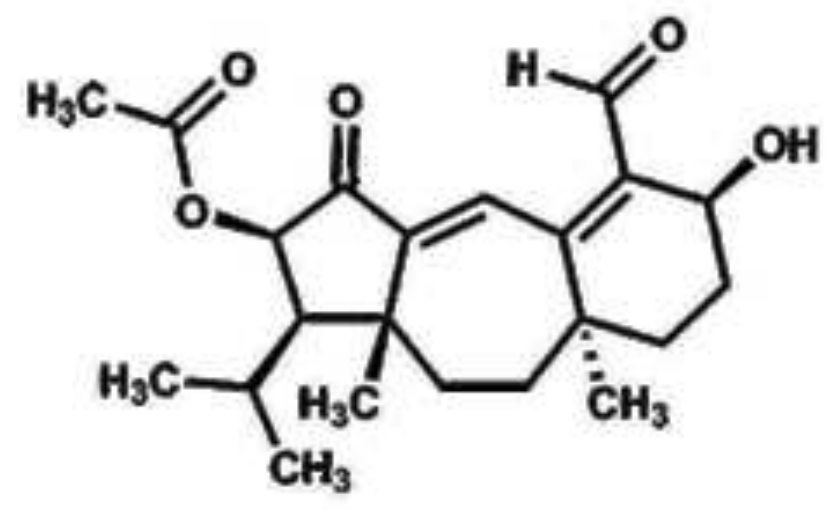

guanacastepene A (29)

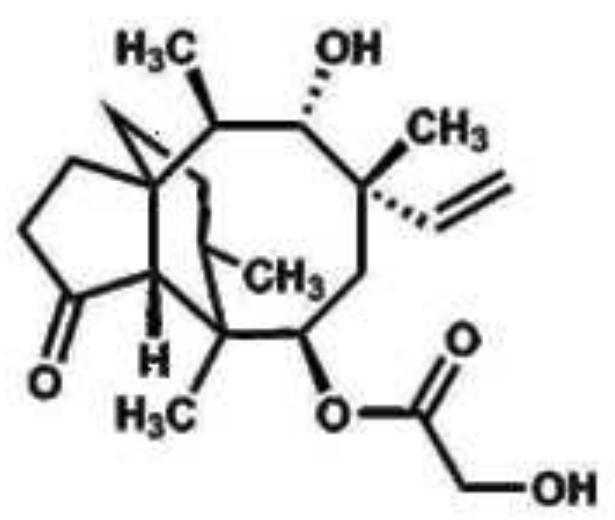

pleuromutilin (31)

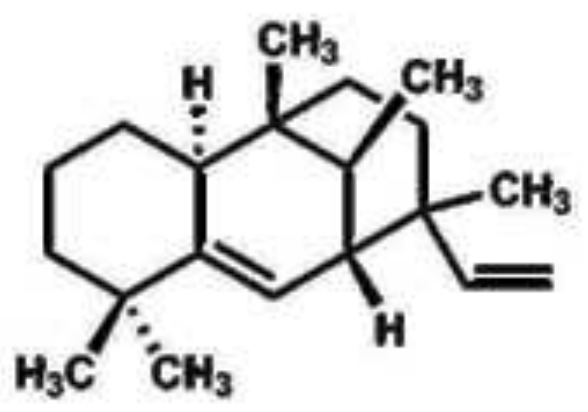

"edaxadiene" (33)

(originally reported strucutre)
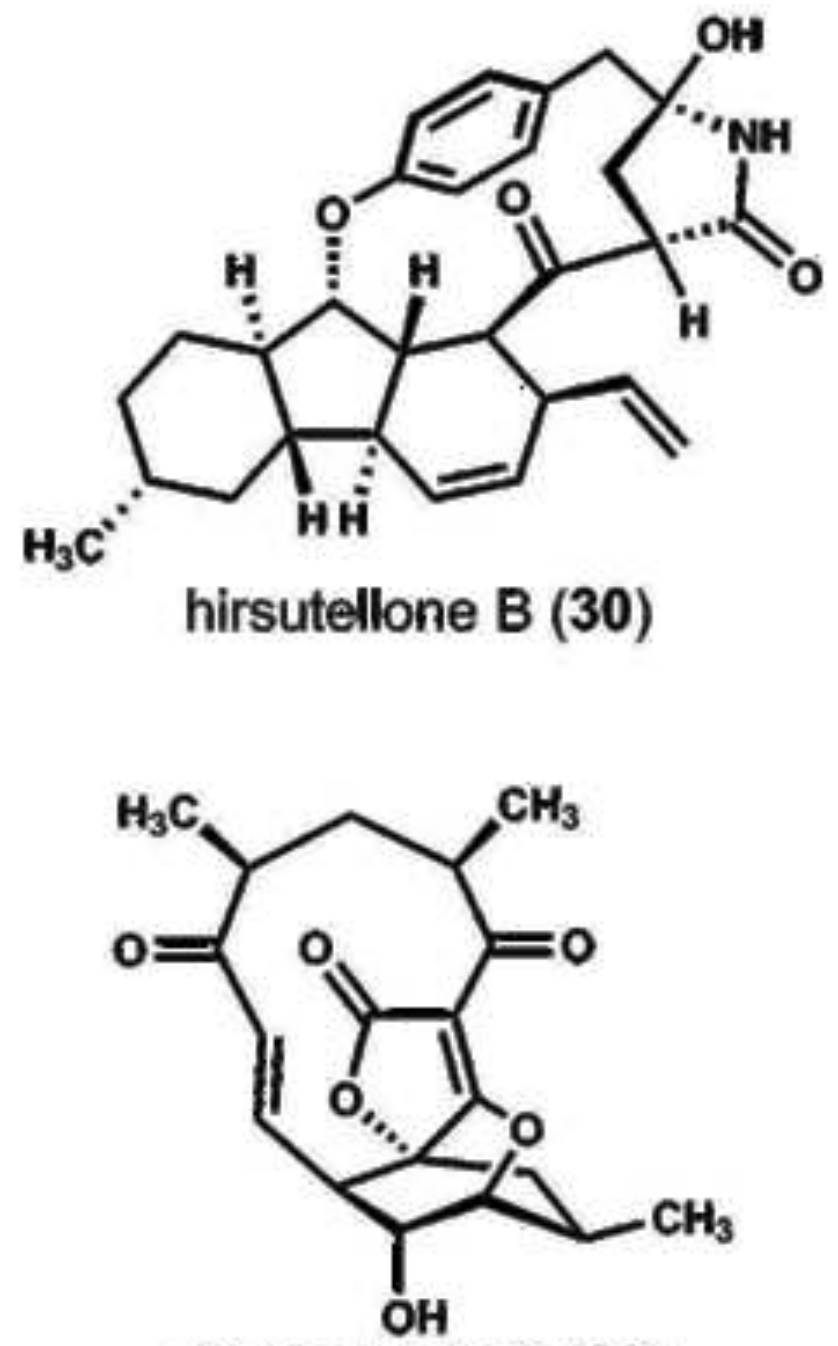

abyssomicin C (32)

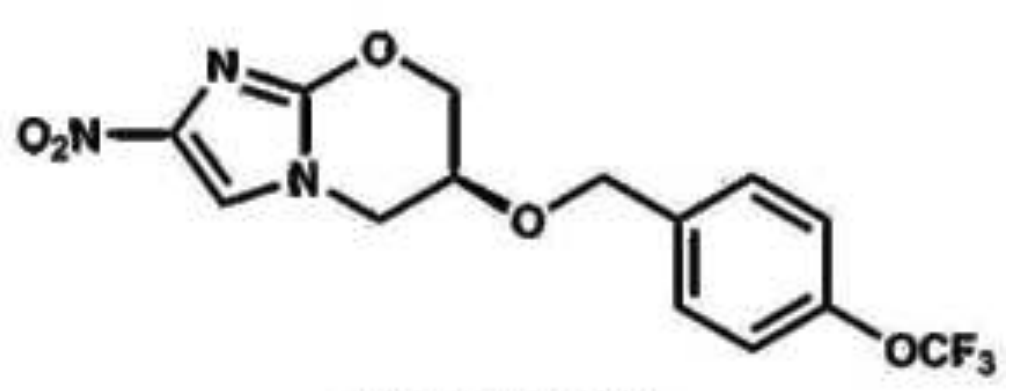

PA-824 (34) 